\title{
The impacts of covid-19 on Indonesian poverty and unemployment
}

Bahri, Muhamad ${ }^{1}$

\begin{abstract}
This study estimates the negative impacts of the COVID-19 on poverty and unemployment in Indonesia. In doing so, this study develops and uses the SD model that reproduced similar patterns in terms of GDP, poverty, and unemployment. Estimated unemployment and estimated poverty under the COVID-19 are calculated for three different economic scenarios: the optimistic, the mid, and the pessimistic scenarios. This study concludes that Indonesia will experience rising unemployment and poverty in ranges (9-10) and (25-26) million people respectively by the end of this year - depending on projected economy growths. This study suggests that existing financial aids are sufficient to support rising unemployment and rising poverty level. However, if the Indonesia government cannot carefully slow the COVID-19 flow, higher financial supports are required to curb the negative impacts of the COVID-19.
\end{abstract}

Keywords: COVID-19, Indonesia, socioeconomic impacts, unemployment, poverty, coronavirus impacts

1 The Graduate Programme of Development Studies (Jurusan Pascasarjana Studi Pembangunan) Bandung Institute of Technology J1 Ganesha 10, Bandung, West Java, Indonesia

Email: databahri@yahoo.com

\section{Introduction}

The COVID-19 has affected almost all countries in all continents across the world. Despite low fatality rates, the negative impacts have reached large-scale socioeconomic impacts such as low employment and possible economic recessions. In reality, regardless of country income, all countries have struggled to escape from the COVID-19 impacts. Recently, despite lower infection rates upon preparedness of more open social and economic activities, the possible second waves have shadowed policymakers. Although some countries have slowed the COVID-19 flow, those affected countries have struggled to curb the negative impacts of the COVID-19.

As one of the emerging markets, Indonesia has attempted to properly handle the pandemic through some policies such as the social restriction policy, restricted travels, and relaxed policies relate to taxes and consumer credits. However, Indonesia has still struggled to sustain its positive economic growths.

Statistics show that the COVID-19 cases were firstly identified on March $1^{\text {st }}, 2020$ after two female Indonesians returned from the International dance festival (Wijaya, 2020; https://covid19.go.id). Following the first two identified cases, the Indonesian COVID-19 cases have increased rapidly, despite the social distancing policy. Up to date, there are about 50,000 cases, 2,000 recoveries, and 3,000 fatalities due to the COVID-19 (https://covid19.go.id). 
The dynamics, the possible impacts, and the government responses relate to the COVID19 have attracted Indonesian scholars to investigate several issues. Some studies (Muhyiddin, 2020; Nurhalimah, 2020) discussed the impacts of the pandemic on social, economic, and education aspects respectively. Other studies (Almuttaqi, 2020; Djalante et al., 2020; Kumala, 2020; Saleh \& Mujahiddin, 2020) explained the government and people's responses on the COVID-19. Few studies (Anawar \& Sukardi, 2020; Setyawan \& Lestari, 2020) focused on possible impacts of policies in eradicating the pandemic spread and correlations between weather and the COVID-19 (Tosepu et al., 2010).

Despite beneficial findings of those studies, there is no available study in investigating the impacts of the COVID-19 on employment, and poverty. Some studies noticed the impacts of the pandemic on unemployment and economic growth (Boissay et al., 2020; Caracciolo et al., 2020; Fornaro, \& Wolf, 2020; Gumede et al., 2020; Loayza, \& Pennings, 2020; McKibbin, \& Fernando, 2020). Even, the IMF itself has offered financial support to affected countries in minimizing the negative impacts (https://www.imf.org/en/Topics/imf-and-covid19/PolicyResponses-to-COVID-19\#I). The IMF has also provided a link - explaining possible policies tackling the negative impacts in affected countries (https://www.imf.org/en/Topics/imf-andcovid19/COVID-Lending-Tracker\#APD). The aforementioned studies enhance our awareness of understanding the negative impacts of the COVID-19 on socioeconomic factors, especially on employment and poverty. This study aims to fill this gap, focusing the negative impacts of the COVID-19 on unemployment and poverty in Indonesia.

\section{Data and Methods}

Socioeconomic data were collected from the Indonesian statistics bureau (www.bps.go.id). For instance, Gross Domestic Product (GDP), poverty, and employment were collected in the period 2000-2019. This study uses the 2000 constant price's GDPs which are also available in the BPS website. The poverty definition used in this study follows the BPS definition, stating that disadvantaged people who cannot fulfill their daily calorie intake about 2,100 per daily capita (https://www.bps.go.id/subject/23/kemiskinan-dan-ketimpangan.html).

To estimate the impacts of the COVID-19 on poverty and unemployment, this study assumes that the economic downturn starts from reduced consumption. This study takes this way as Indonesia GDP has been mainly dominated by consumption about $61 \%$ of the total GDP (BPS, 2018; Soemartini, 2007; Wiranthi, 2014). So when the Indonesian economy is under pressure, consumption is expected to experience a significant loss (Suryahadi et al., 2020).

The application of the system dynamics (SD) approach has been applied in some subjects such as macro economy and health issues (Sterman, 2001). Furthermore, Sterman (1991) affirmed that one benefit of the SD approach is enabling policymakers to solve critically complex issues through the system-thinking concept. The concept captures important features such as stock-flow, time delays, non-linearity, and feedback - which are also underlying features of the real world. Owing to this, this study applies the SD approach in understanding the impacts of the COVID-19 on poverty and unemployment in Indonesia. 


\section{Discussion and results}

\section{The Indonesia economy}

Indonesia has experienced significant economic growths since the Asian monetary crisis of 1998. Since an economic contraction about $13 \%$ in 1998, Indonesia has experienced promising economic growths about 5-7 \% per year as seen in figure 1. Consumption has dominated Indonesian Gross Domestic Product (GDP) about $60 \%$ of the total GDP (Bahri, 2008, BPS, 2018). Owing to dominance of household consumption, Indonesia has still led a positive economic growth during the economic crisis of 2008.

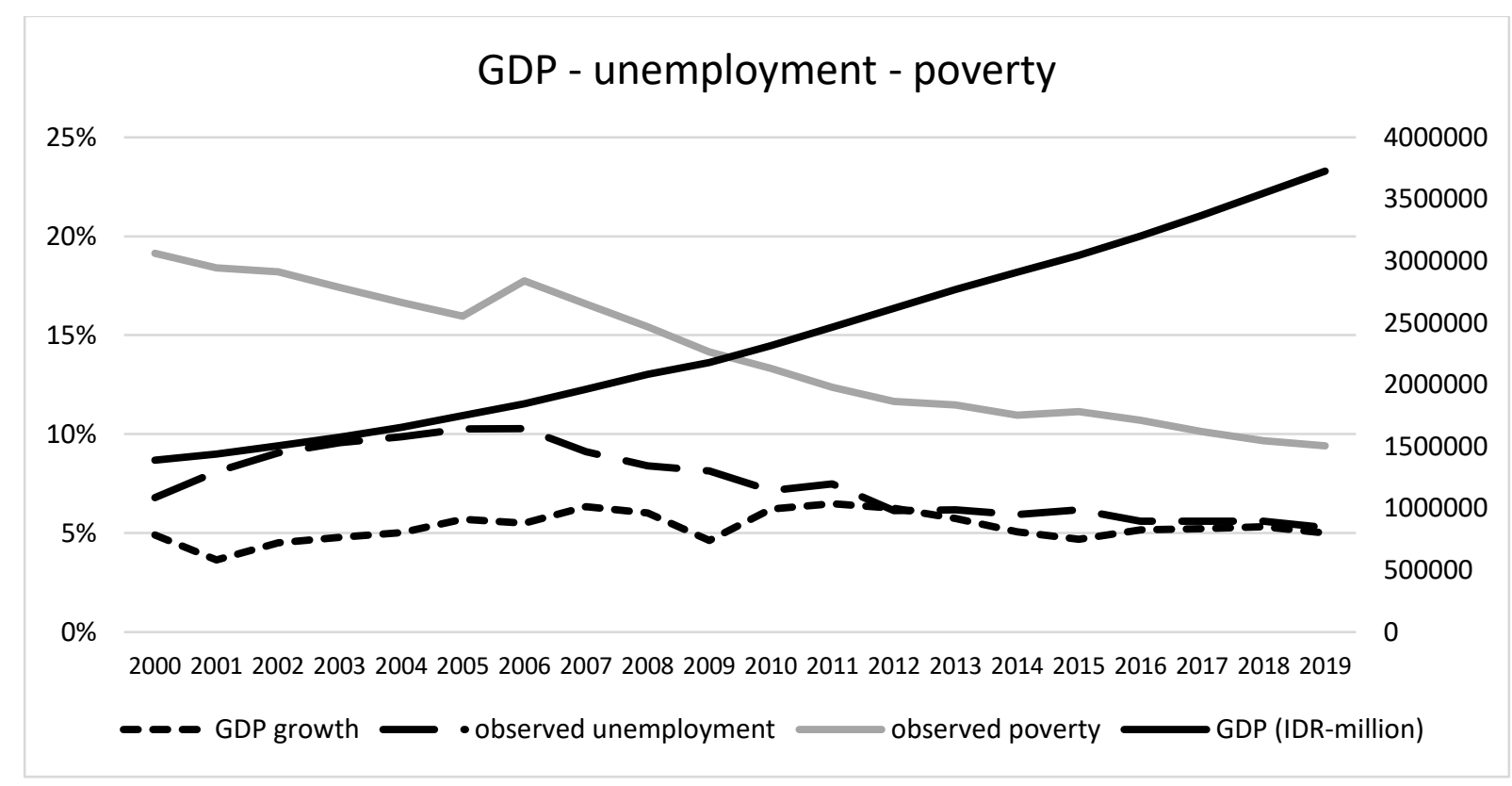

Figure 1. Indonesian GDP - unemployment and poverty (2000-2019)

Some studies (Suryahadi et al., 2006; Van Leeuwen, \& Földvári, 2016; Yusuf, \& Sumner, 2017) confirmed the positive impacts of Indonesian economic growth on poverty reduction. It was found that every 1 percent economic growth has led to 0.5 percent of poverty reduction in Indonesia. As seen in figure 1, the number of poor has reduced subject to positive economic growths.

\section{System Dynamics Model}

The system dynamics model was derived from other studies (Bahri, 2008; Forrester, 1985). In understanding the Indonesian macroeconomic model, the SD model is separated into three sub-models as seen in figures 2-4. The first sub-model is the potential output (PTY) and output (Y or GDP) sub-model that determines relationships between PTY and GDP. Please note that the model documentation is available in appendix A. 


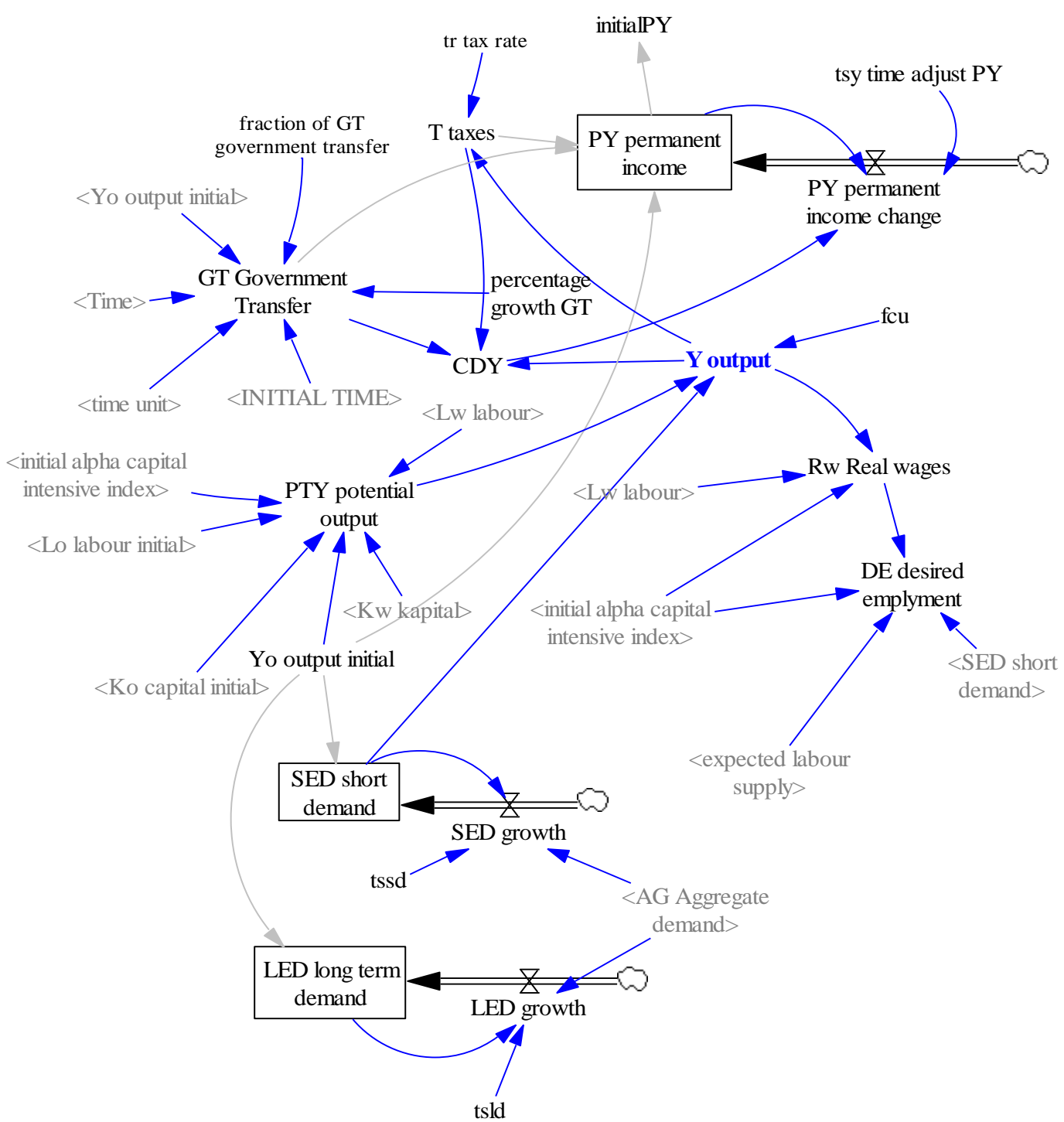

Figure 2. The sub-model of the potential output (PTY) and output (Y=GDP)

The second sub-model is called the capital and labor (CL) sub-model that describes relationships between population, labor, and capital. In this sub-model, a relationship between GDP, poverty, and employment is defined based on historical data. The last sub-model is called the Aggregate Demand (AG) sub-model, explaining relationships between GDP, AG, and poverty level. 


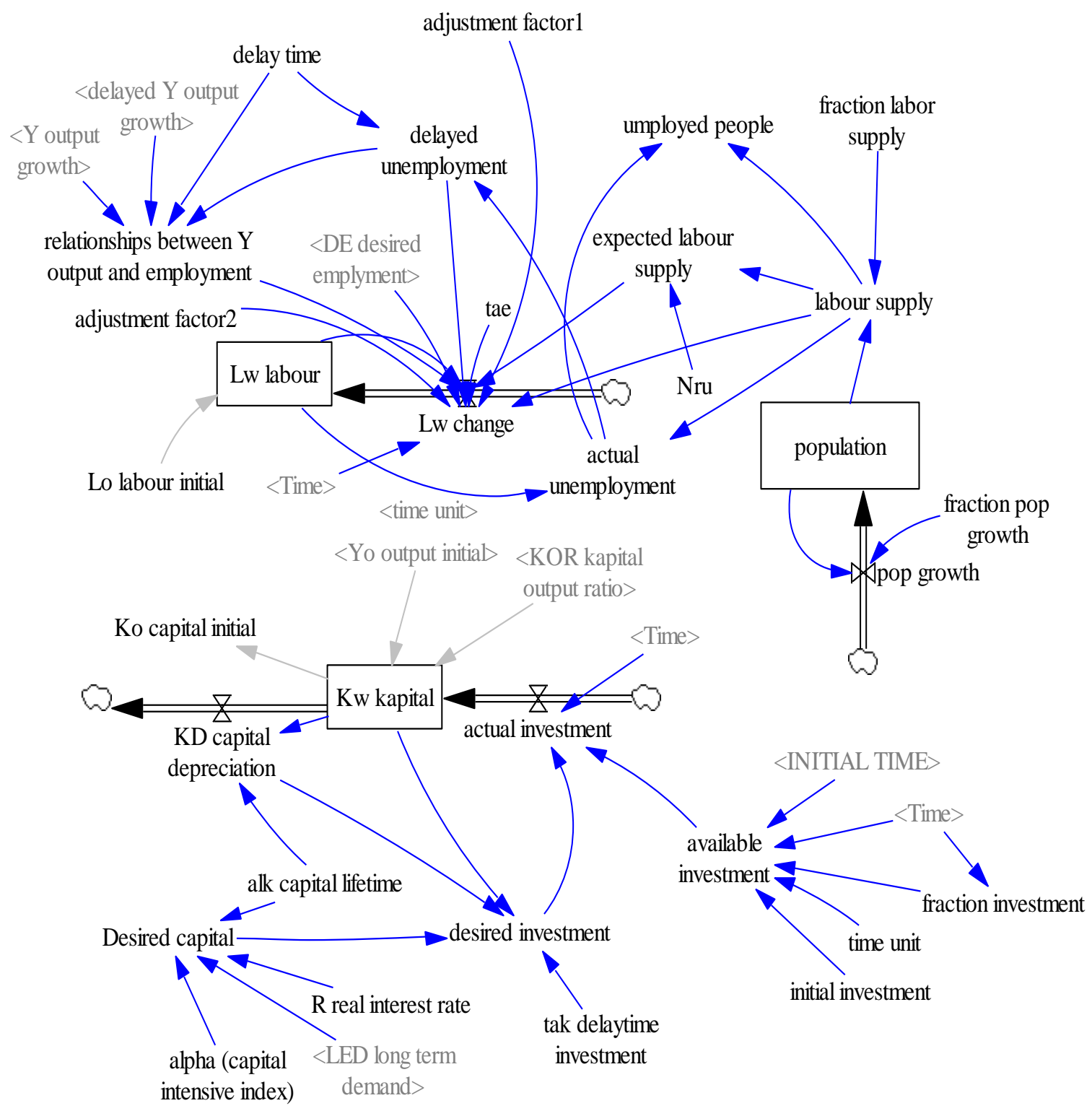

Figure 3. The sub-model of the Capital and Labor (CL) 


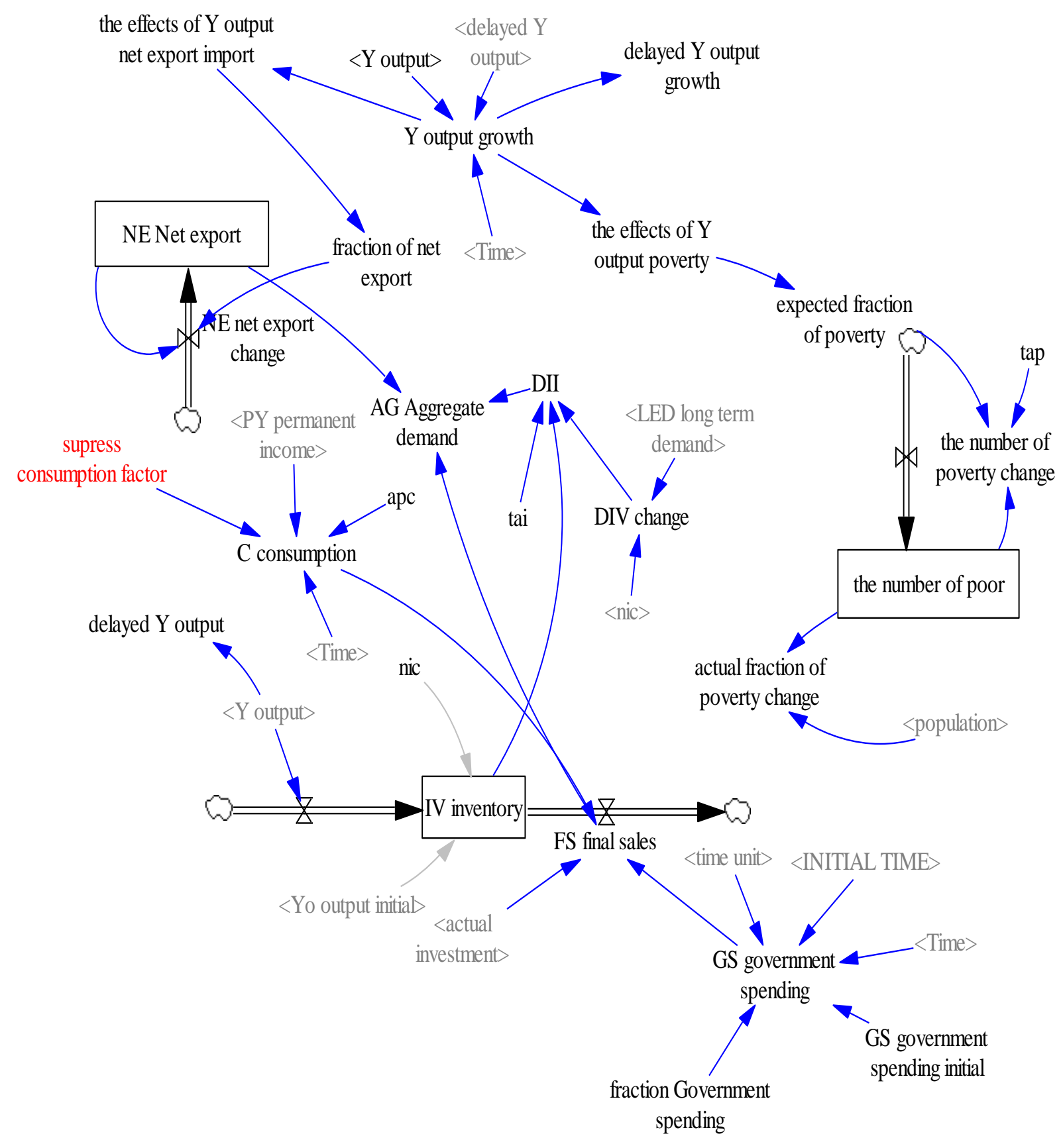

Figure 4. The sub-model of the Aggregate Demand (AG)

The model performance in estimating observed GDP, observed poverty, and observed employment can be seen in figures 5-7. Figures 5-7 show that the SD model can reproduce similar observed GDP and observed poverty. For unemployment, the SD model can reproduce similar unemployment patterns in the last decade (2010-2019). As seen in table 1, MAPEs of the SD model are less than $20 \%$ which mean the SD model can predict the observed system relatively accurate (Hanke et al., 2001; Hoshmand, 2009). 
observed Indonesia GDP and simulated Indonesian GDP

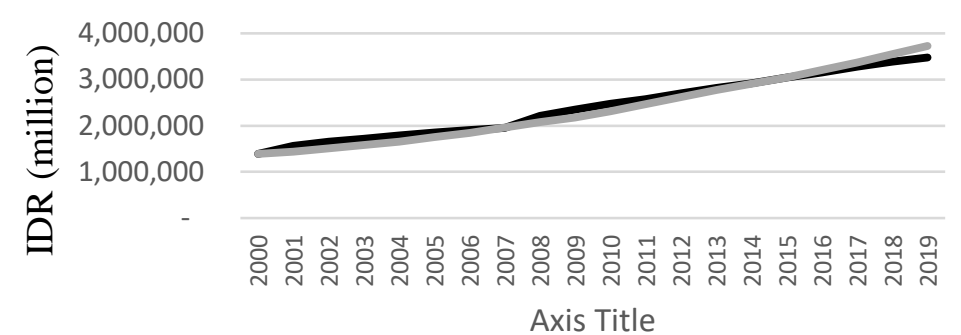

$\longrightarrow$ simulated GDP $\quad$ observed GDP

Figure 5. Simulated and observed GDP in Indonesia

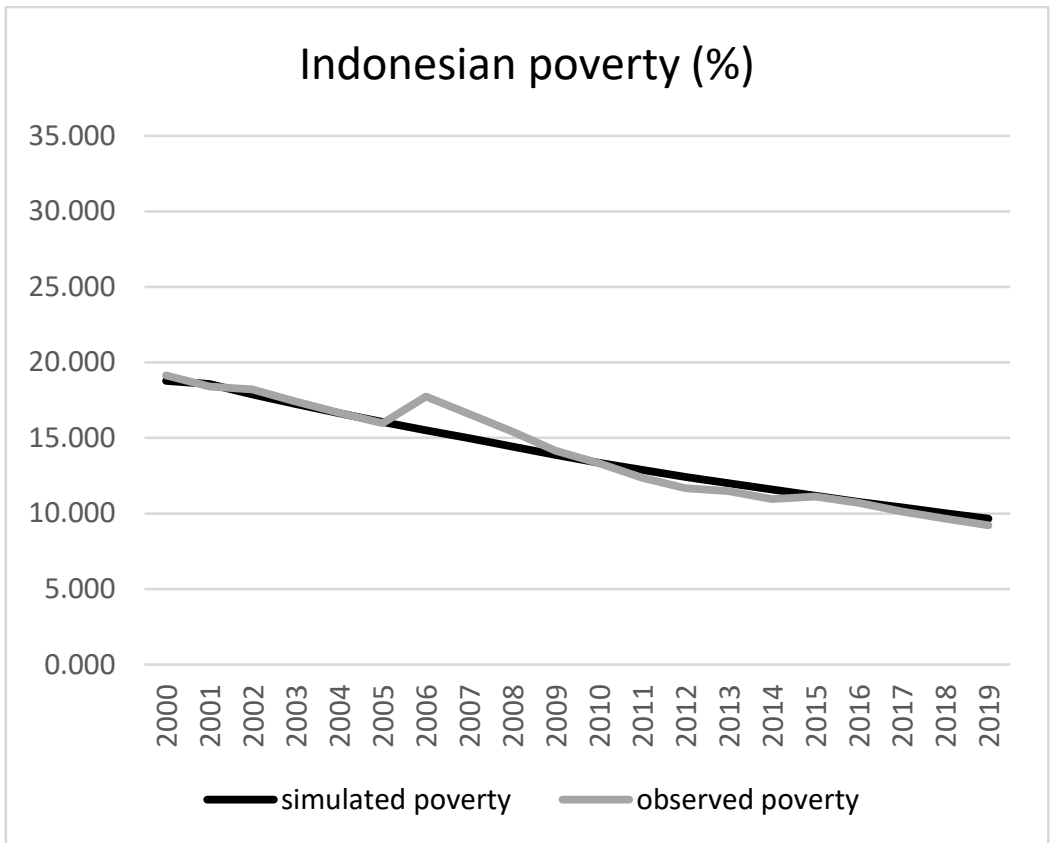

Figure 6. Simulated and observed poverty in Indonesia

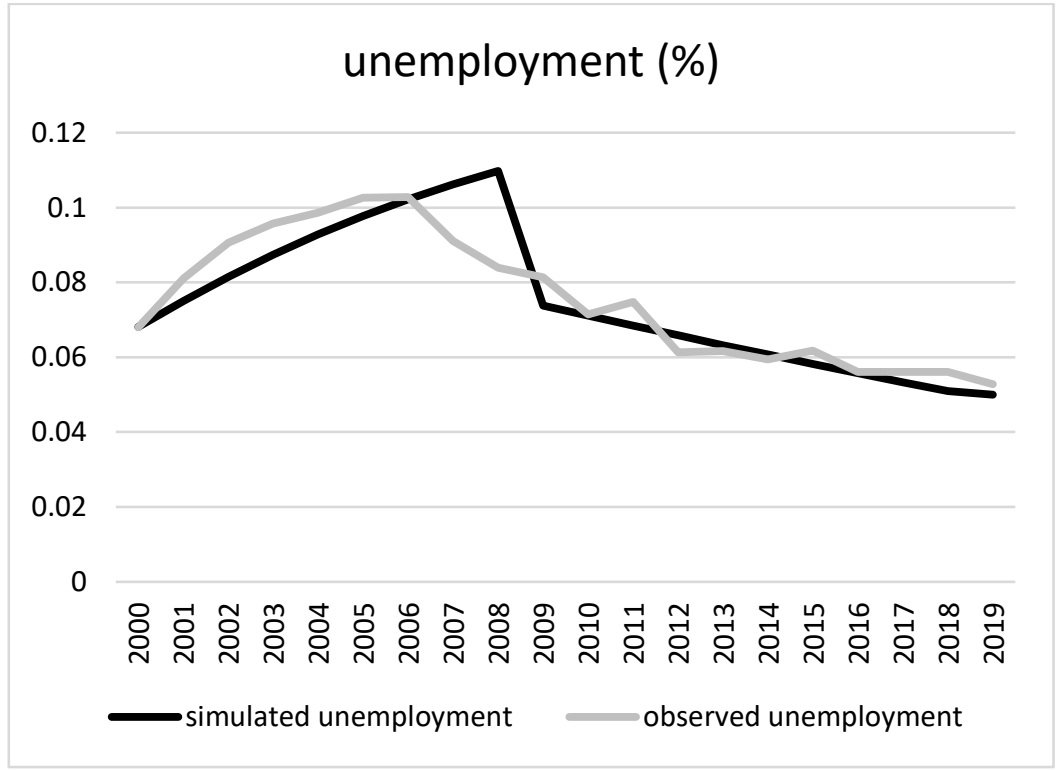

Figure 7. Simulated and observed employment in Indonesia 

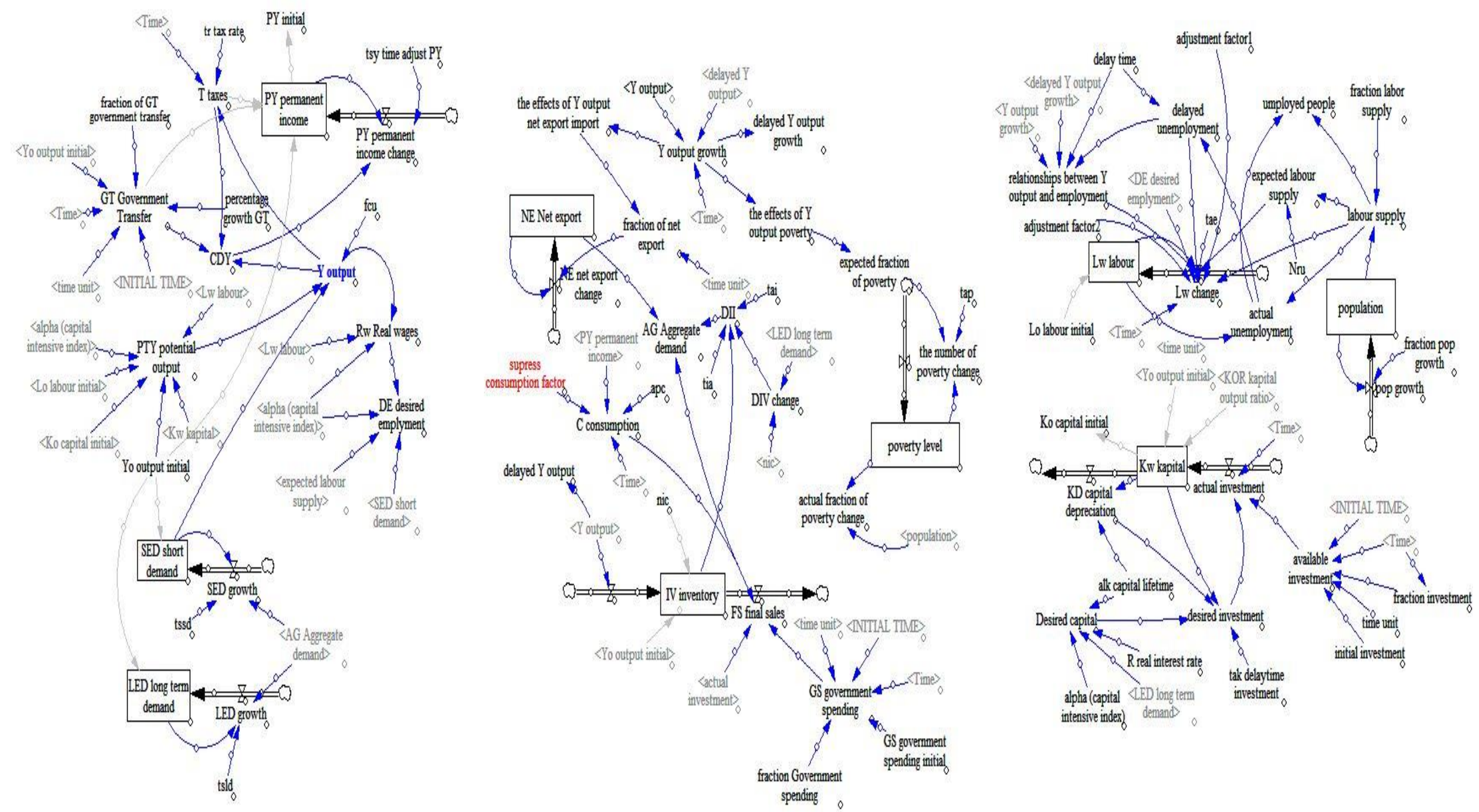

Figure 8. A completed stock-flow model (Please appendix A for the model documentation) 


\begin{tabular}{|c|l|c|}
\hline No & \multicolumn{1}{|c|}{ Variables } & MAPE \\
\hline 1 & Simulated GDP & $3.5 \%$ \\
\hline 2 & Simulated poverty level & $4.5 \%$ \\
\hline 3 & Simulated unemployment & $7 \%$ \\
\hline
\end{tabular}

Table 1. MAPE for important variables

\section{Estimated unemployment and poverty level}

To estimate the poverty level and unemployment during the COVID-19, this study evaluates three different scenarios. The first scenario is the optimistic scenario where Indonesian economic growth will be about $2.5 \%$ by the end of this year (Wardhana et al., 2020). The second one is the mid scenario where Indonesia will experience an economic growth of about $0.5 \%$ (Wardhana et al., 2020). The last one is the pessimistic scenario in which Indonesia will experience a negative GDP growth of about $-3.5 \%$ (Wardhana et al., 2020).

\begin{tabular}{|c|c|c|c|}
\hline No & Institutions & The world & Indonesia \\
\hline 1 & Asian Development Bank & $(-2.3-4.8)$ & $2.5 \%$ \\
& & $\%$ & $(3,819,998.9)$ \\
\hline 2 & IMF (https://www.imf.org/external/datamapper/ & $-3 \%$ & $0.5 \%$ \\
& NGDP_RPCH@WEO/OEMDC/ADVEC/WEOWORLD) & & $(3,745,462.4)$ \\
& & & $(-3.5-2.1) \%$ \\
3 & World Bank & n.a. & $(3,596,389.2)$ \\
\hline
\end{tabular}

Table 2. Projected economic growth in 2020 (estimated GDP in IDR million)

To simulate each scenario, the SD model is embedded by a variable namely "suppress consumption factor" as seen in figure 4. This variable represents a consumption drop in 2020. Consumption is projected to decrease about $11.5 \%, 19 \%$, and $33.5 \%$. Reduced consumptions correspond with the economic growth of the first, the second, and the third scenario respectively.

As seen in figure 9, the number of poverty and unemployment tends to increase for the first, the second, and the third scenario. As expected, the number of unemployed and poverty are the highest ones in the third scenario. 


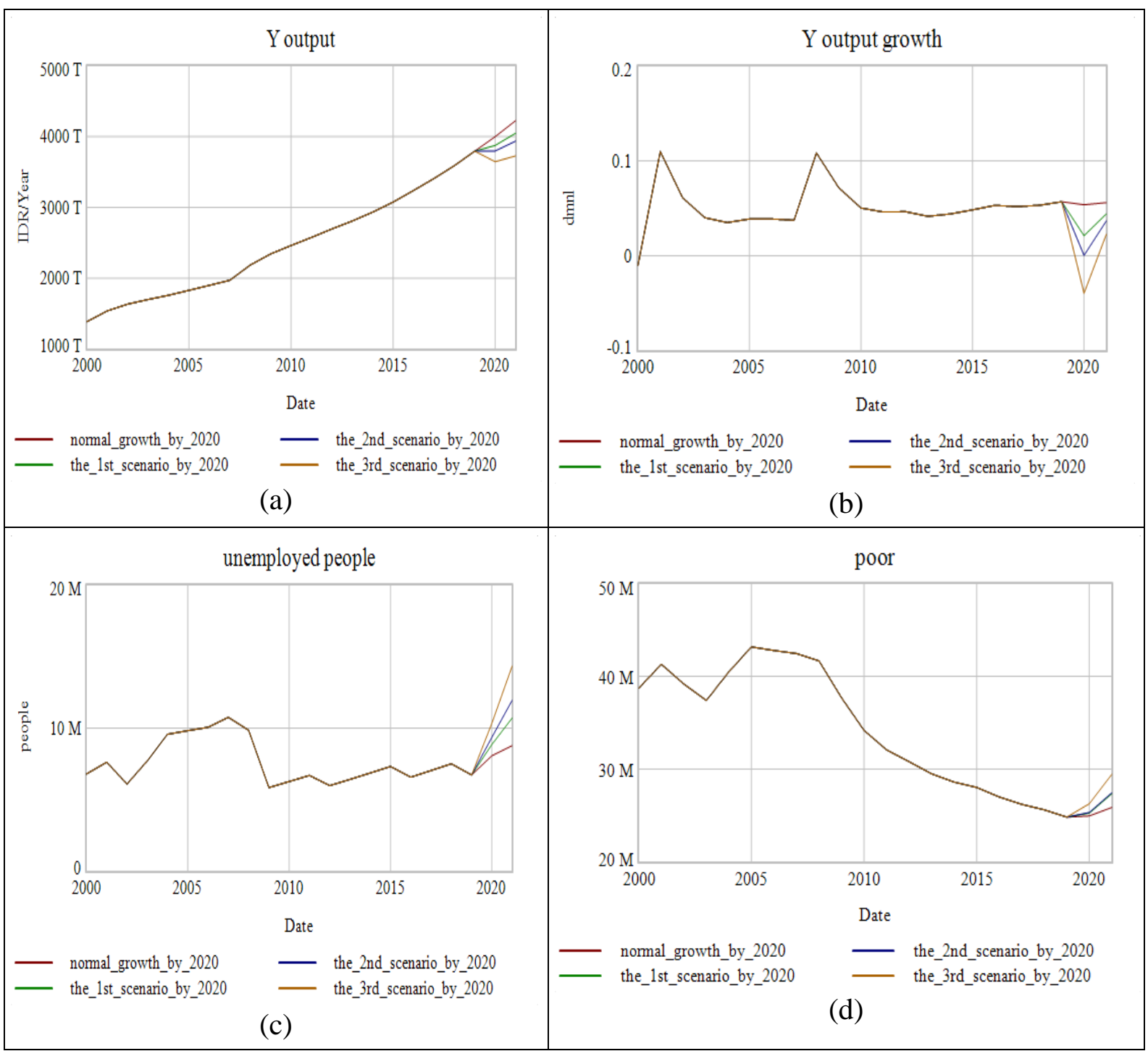

Figure 9. Comparison outputs for different scenarios by 2020

Figure 9 displays the estimated unemployment and poverty for each scenario by 2100. It is estimated that unemployment will be about $6.76 \%$ to $7.89 \%$ for the first to the third scenarios by 2100 . This corresponds with 8.9 million and 10.3 million unemployed people respectively. This study also estimated rising poverty about $8.79 \%$ to $9.46 \%$ depending on the scenarios by 2100. This means that rising poverty will be about 23.75 million to 25.56 million by 2020 . 


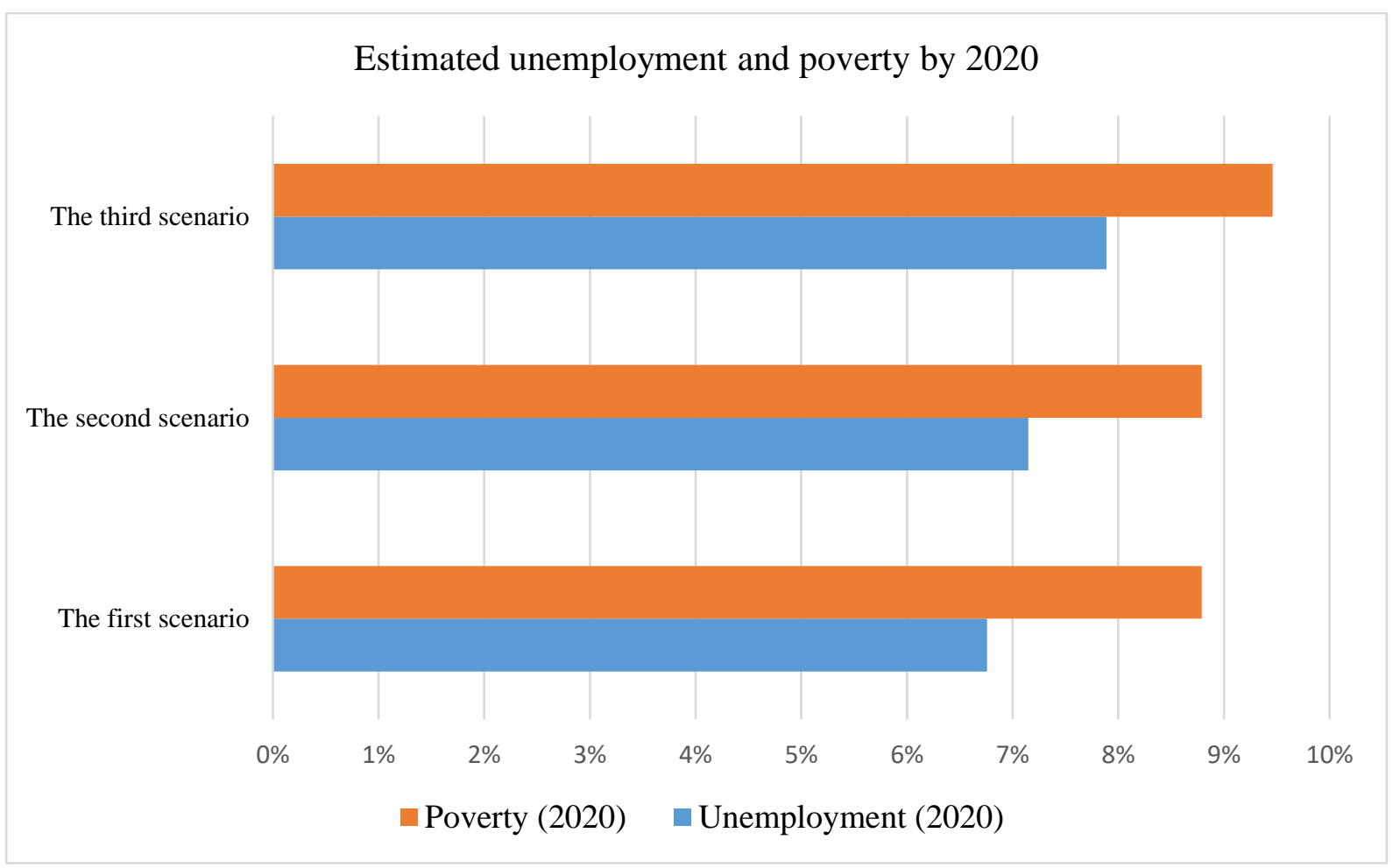

Figure 10. Estimated unemployment and poverty by 2020

The Indonesia government has provided support to rising poverty and rising unemployment under the pandemic. The proposed funding is about IDR 677.2 trillion that is about IDR 87.55 trillion to support medical facilities, and IDR 385.75 trillion to relief industries - please see table 4 for details. For the safety net, the government provides about IDR 203.9 trillion. Table 2 shows that the potential poverty level is about 25.56 million people or 5.6 million households - assuming a family size is about 4.58 people (BPS, 2019). This means that the social safety net can support affected families about IDR 700,000.monthly for three months in the worstcase scenario.

Funding support in health, economy, and social safety nets (IDR trillion)

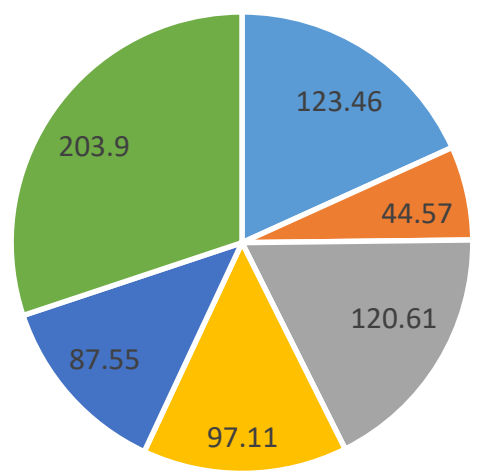

- Small enterprises $\|$ Corporate/state owned companies $\|$ Tax relief $\approx$ Sectoral aids $\|$ Health $\|$ Social safety net

Figure 11. The government support for the Covid-19 (Kementerian Keuangan RI, 2020) 
The Indonesian poverty line is about IDR 440,500/person/month or about 2 million/family/month (BPS, 2019). Assuming that a consumption drop is similar to an income loss $(33.3 \%)$, the safety net of IDR 700,000 per family could relatively curb the income loss during the COVID-19 time.

As this support is only available for about 3 months, this study also suggests that the government should consider and monitor the impacts of the COVID-19 regularly to anticipate rising unemployment and rising poverty. The most importantly, the government should work together with other stakeholders to hamper the COVID-19 spread across the country.

\section{Conclusion}

This study applied the SD approach to estimate the impacts of the COVID-19 on Indonesian unemployment and poverty. The SD model can reproduce similar GPD, unemployment, and poverty in the period 2000-2019. As such, the model can be used to forecast projected unemployment and poverty owing to the COVID-19.

This study also suggests that available funding for the safety net is sufficient to support affected households for about three months. In that case, the government should monitor and handle the COVID-19 flow properly so that the society and the industries can return to their normal activities at the expected time. If the impacts of the COVID-19 is longer than expectation, the government should prepare higher financial aids to support rising unemployment and poverty level. 


\section{References}

Almuttaqi, A. I. (2020). Kekacauan Respons terhadap COVID-19 di Indonesia. The Insigjts, $1(13), 1-7$.

Anwar, H., \& Sukardi, L. (2020). Model of COVID-19 Spread Control Using the Dynamic System Approach in West Nusa Tenggara Province, Indonesia. Sumatra Journal of Disaster, Geography and Geography Education, 4(1), 5-10.

Baldwin, R., \& di Mauro, B. W. (2020). Economics in the Time of COVID-19. A VoxEU. org Book, Centre for Economic Policy Research, London. Accessed, 26.

Bahri, M. K. (2008). Achieving the vision 2030: An Indonesia macroeconomic model using system dynamics approach. Unpublished master thesis. Graduate Program of Development Studies. Bandung Institute of Technology. https://www.researchgate.net/publication/236859486_Indonesia's_Macroeconomic_Model_us ing_System_Dynamics_Approach

BPS. (2018). Statistical Yearbook of Indonesia 2018. Badan Pusat Statistik, Jakarta, 228.

BPS. (2019). Profil kemiskinan Indonesia September 2019. Badan Pusat Statistik, Jakarta,.

Boissay, F., Rees, D., \& Rungcharoenkitkul, P. (2020). Dealing with Covid-19: understanding the policy choices (No. 19). Bank for International Settlements.

Caracciolo, G., Cingano, F., Ercolani, V., Ferrero, G., Hassan, F., Papetti, A., \& Tommasino, P. Covid-19 and Economic Analysis: a Review of the Debate. . Retrieved on $15^{\text {th }}$ June, 2020 from https://www.bancaditalia.it/media/notizie/2020/Covid-literature-newsletter-n2.pdf

Darman, D. (2013). Pengaruh Pertumbuhan Ekonomi terhadap Tingkat Pengangguran: Analisis Hukum Okun. The Winners, 14(1), 1-12.

Djalante, R., Lassa, J., Setiamarga, D., Mahfud, C., Sudjatma, A., Indrawan, M., ... \& Gunawan, L. A. (2020). Review and analysis of current responses to COVID-19 in Indonesia: Period of January to March 2020. Progress in Disaster Science, 100091.

Emanuel, E. J., Persad, G., Upshur, R., Thome, B., Parker, M., Glickman, A., ... \& Phillips, J. P. (2020). Fair allocation of scarce medical resources in the time of Covid-19.

Fornaro, L., \& Wolf, M. (2020). Covid-19 coronavirus and macroeconomic policy. Retrieved on $15^{\text {th }}$ June, 2020 from https://homepage.univie.ac.at/ma.wolf/assets/files/corona_v2.pdf

Forrester, N. B. (1982). A dynamic synthesis of basic macroeconomic theory: implications for stabilization policy analysis (Doctoral dissertation, Massachusetts Institute of Technology).

Forrester, J. W. (2007). System dynamics - a personal view of the first fifty years. System Dynamics Review: The Journal of the System Dynamics Society, 23(2-3), 345-358.

Gumede, W., Bob, U., de Beer, D., Lues, R., \& Anelich, L. (2020). Position Paper: Priority Setting For Interventions In Pre-And Post-Pandemic Management: The Case Of Covid-19.

Retrieved on $15^{\text {th }}$ June, 2020 from https://www.satn.org.za/wpcontent/uploads/2020/06/SATN-COVID-19-Position-Paper-030620.pdf 
Hanke, J. E., Reitsch, A. G., \& Wichern, D. W. (2001). Business forecasting (Vol. 9). Upper Saddle River, NJ: Prentice Hall.

Hoshmand, A. R. (2009). Business forecasting: a practical approach. Routledge.

Kementerian Keuangan RI. (2020). APBN Kita - June 2020. Kementerian Keuangan Republik Indonesia. Jakarta, Indonesia

Kumala, R. D. M. (2020). Legal Analysis of Government Policy on Large Scale Social Restrictions in Handling Covid-19. The Indonesian Journal of International Clinical Legal Education, 2(2), 181-200.

Loayza, N. V., \& Pennings, S. (2020). Macroeconomic policy in the time of COVID-19: A primer for developing countries. The world bank group

McKibbin, W. J., \& Fernando, R. (2020). The global macroeconomic impacts of COVID-19: Seven scenarios.

Muhyiddin, M., \& Wardhana, D. (2020). Covid-19 Outbreak and Development Planning in Indonesia. The Indonesian Journal of Development Planning, 4(1).

Nurhalimah, S. (2020). Covid-19 dan Hak Masyarakat atas Kesehatan. SALAM: Jurnal Sosial dan Budaya Syar-i, 7(6).

Nurhalimah, S. (2020). Covid-19 dan Hak Masyarakat atas Kesehatan. SALAM: Jurnal Sosial dan Budaya Syar-i, 7(6).

Rahayu, R. N. (2020). Analisis Berita Hoax Covid-19 di Media Sosial di Indonesia. Jurnal Ekonomi, Sosial \& Humaniora, 1(09), 60-73.

Saleh, A., \& Mujahiddin, M. (2020). Challenges and Opportunities for Community Empowerment Practices in Indonesia during the Covid-19 Pandemic through Strengthening the Role of Higher Education. Budapest International Research and Critics Institute (BIRCIJournal): Humanities and Social Sciences, 3(2), 1105-1113.

Setyawan, F. E. B., \& Lestari, R. (2020). Challenges of Stay-At-Home Policy Implementation During The Coronavirus (Covid-19) Pandemic In Indonesia. Jurnal Administrasi Kesehatan Indonesia, 8(2), 15-20.

Soemartini, S. (2007). The Measurement of Marginal Propensity to Consume (MPC) Based on Indonesian, s Consumption Pattern for the Period 2000-2006. STATISTIKA: Journal of Theoretical Statistics and Its Applications, 7(2).

Suryahadi, A., Suryadarma, D., \& Sumarto, S. (2006). The Effects of Location and Sectoral Components of Growth (No. 22550). East Asian Bureau of Economic Research.

Suryahadi, A., Al Izzati, R., \& Suryadarma, D. (2020). The Impact of COVID-19 Outbreak on Poverty: An Estimation for Indonesia. SMERU Working Paper. 
Tosepu, R., Gunawan, J., Effendy, D. S., Lestari, H., Bahar, H., \& Asfian, P. (2020). Correlation between weather and Covid-19 pandemic in Jakarta, Indonesia. Science of The Total Environment, 138436.

Trimurti, C. P., \& Komalasari, Y. (2014). Determinants of unemployment: Empirical evidences from 7 Province in Indonesia. Scientific Research Journal (SCIRJ), 2(8), 5-9.

Van Leeuwen, B., \& Földvári, P. (2016). The development of inequality and poverty in Indonesia, 1932-2008. Bulletin of Indonesian economic studies, 52(3), 379-402.

Wardhana, D. (2020). Kajian Kebijakan dan Arah Riset Pasca-Covid-19. The Indonesian Journal of Development Planning, 4(2), 223-239.

Wijaya, W. (2020). Studi Komparasi Infografis Pencegahan Virus Corona. Deskovi: Art and Design Journal, 3(1), 7-20.

Wiranthi, P. E. (2014). Analisis Determinan pengeluaran Konsumsi makro rumah tangga di Indonesia. Signifikan: Jurnal Ilmu Ekonomi, 3(2).

Yusuf, A. A., \& Sumner, A. (2017). Multidimensional poverty in Indonesia: How inclusive has economic growth been? (No. 2017-09). 
Appendix A.

Documentation of macroeconomic_models_covid-19_2020 Model Assessment Results

\begin{tabular}{|l|c|}
\hline \multicolumn{1}{|c|}{ Model Information } & Number \\
\hline Total Number of Variables & 92 \\
\hline Total Number of State Variables & 13 \\
\hline (Level+Smooth+Delay Variables) & $(14.1 \%)$ \\
\hline $\begin{array}{l}\text { Total Number of Stocks (Stocks in } \\
\text { Level+Smooth+Delay Variables) }\end{array}$ & 15 \\
\hline Total Number of Macros & $(16.3 \%)$ \\
\hline Time Unit & 0 \\
\hline Initial Time & Year \\
\hline Final Time & 0 \\
\hline Reported Time Interval & 21 \\
\hline Time Step & 1 \\
\hline \hline Model Is Fully Formulated & 0.0078125 \\
\hline
\end{tabular}




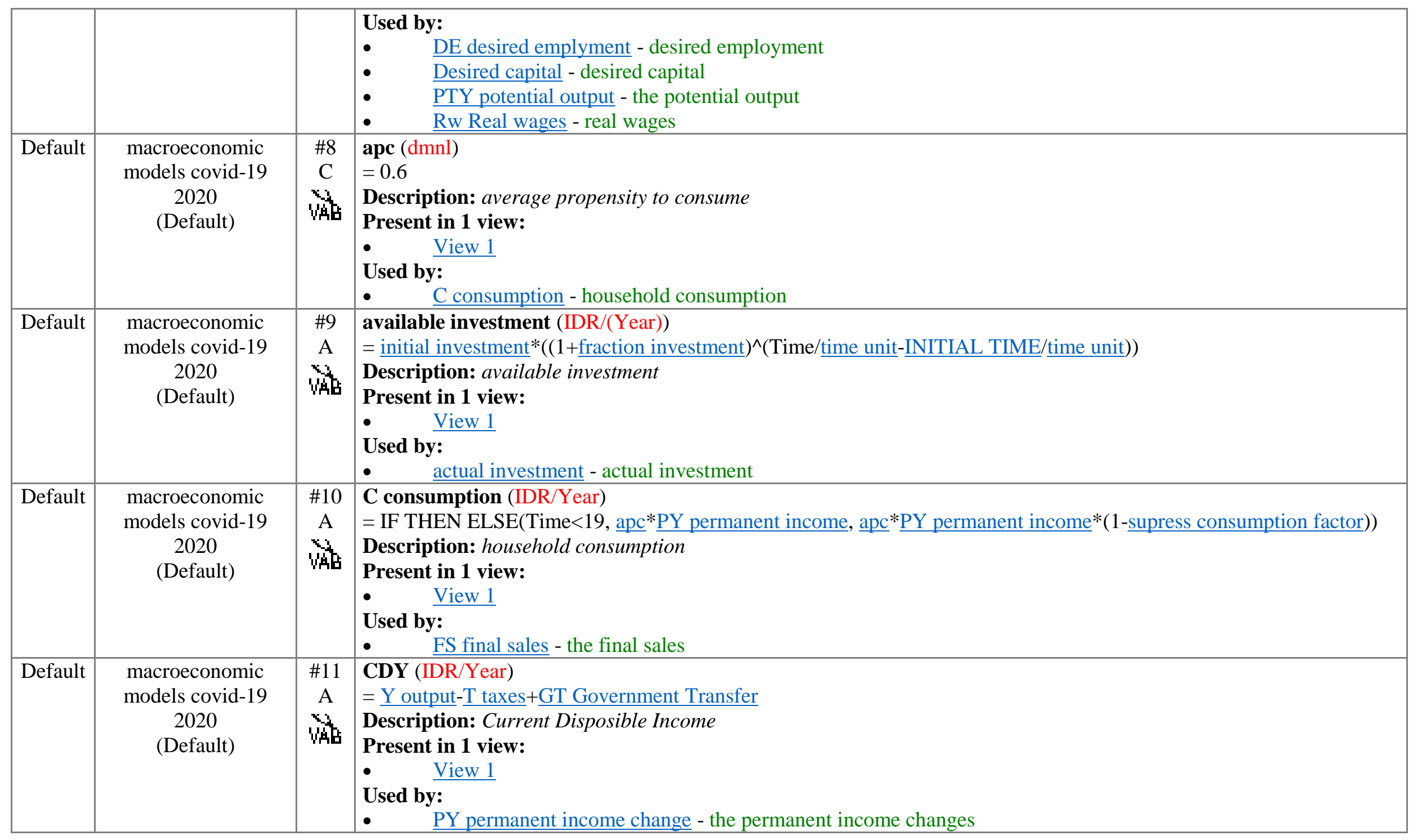




\begin{tabular}{|c|c|c|c|}
\hline Default & $\begin{array}{c}\text { macroeconomic } \\
\text { models covid-19 } \\
2020 \\
\text { (Default) }\end{array}$ & $\begin{array}{c}\# 12 \\
\text { A } \\
\text { VAB }\end{array}$ & $\begin{array}{l}\text { DE desired emplyment (people) } \\
\left.=\text { MIN }\left(\left(\text { SED short demand } *(1-" \text { alpha (capital intensive index })^{\prime}\right) / \text { Rw Real wages }\right), \text { expected labour supply }\right) \\
\text { Description: desired employment } \\
\text { Present in } 1 \text { view: } \\
\text { • } \quad \text { View } 1 \\
\text { Used by: } \\
\qquad \quad \text { Lw change - changes in employment }\end{array}$ \\
\hline Default & $\begin{array}{c}\text { macroeconomic } \\
\text { models covid-19 } \\
2020 \\
\text { (Default) }\end{array}$ & $\begin{array}{l}\# 13 \\
\text { DE }\end{array}$ & $\begin{array}{l}\text { delayed unemployment } \\
\text { = DELAY1I(actual unemployment, } 1 \text {, actual unemployment }) \\
\text { Description: one year lagged unemployment } \\
\text { Present in } 1 \text { view: } \\
\text { - } \quad \text { View } 1 \\
\text { Used by: } \\
\quad \quad \text { Lw change - changes in employment } \\
\text { the actual effects of Y output employment - the effects of GDP on umployment }\end{array}$ \\
\hline Default & $\begin{array}{c}\text { macroeconomic } \\
\text { models covid-19 } \\
2020 \\
\text { (Default) }\end{array}$ & $\begin{array}{c}\# 14 \\
\text { DE }\end{array}$ & $\begin{array}{l}\text { delayed Y output (IDR/Year) } \\
\text { = DELAY FIXED (Y output, } 1,0.049) \\
\text { Description: delayed output }(G D P) \text { - one year lagged GDP } \\
\text { Present in } 1 \text { view: } \\
\text { - View } 1 \\
\text { Used by: } \\
\text { - Y output growth - output Y growth - (GDP growth) }\end{array}$ \\
\hline Default & $\begin{array}{c}\text { macroeconomic } \\
\text { models covid-19 } \\
2020 \\
\text { (Default) }\end{array}$ & $\begin{array}{l}\# 15 \\
D E\end{array}$ & $\begin{array}{l}\text { delayed Y output growth }(\mathrm{dmnl}) \\
\text { = DELAY FIXED (Y output growth, } 1,-0.01) \\
\text { Description: } \text { one-year output growth - ( one-year lagged GDP growth) } \\
\text { Present in } 1 \text { view: } \\
\text { - } \quad \text { View } 1 \\
\text { Used by: } \\
\text { - the actual effects of Y output employment - the effects of GDP on umployment }\end{array}$ \\
\hline Default & $\begin{array}{c}\text { macroeconomic } \\
\text { models covid-19 } \\
2020 \\
\text { (Default) }\end{array}$ & $\begin{array}{c}\# 16 \\
\text { A } \\
\text { Vatb }\end{array}$ & $\begin{array}{l}\text { Desired capital (IDR) } \\
=(\text { "alpha (capital intensive index }) ") * \text { LED long term demand } /((1 / \text { alk capital lifetime })+\underline{R} \text { real interest rate }) \\
\text { Description: desired capital } \\
\text { Present in } 1 \text { view: } \\
\text { • } \quad \text { View } 1 \\
\text { Used by: }\end{array}$ \\
\hline
\end{tabular}




\begin{tabular}{|c|c|c|c|}
\hline & & & - $\quad$ desired investment - desired investment \\
\hline Default & $\begin{array}{c}\text { macroeconomic } \\
\text { models covid-19 } \\
2020 \\
\text { (Default) }\end{array}$ & $\begin{array}{c}\# 18 \\
\text { A } \\
\text { VAb }\end{array}$ & $\begin{array}{l}\text { DII }(\mathrm{IDR} / \text { Year }) \\
=\text { MAX }(\mathrm{DIV} \text { change, }(\text { DIV change-IV inventory }) / \text { tai) } \\
\text { Description: desired inventory investment } \\
\text { Present in } \mathbf{1} \text { view: } \\
\text { - } \quad \text { View } 1 \\
\text { Used by: } \\
\text { - AG Aggregate demand - the aggregate demand }\end{array}$ \\
\hline Default & $\begin{array}{c}\text { macroeconomic } \\
\text { models covid-19 } \\
2020 \\
\text { (Default) }\end{array}$ & $\begin{array}{c}\# 19 \\
\text { A } \\
\text { VAb }\end{array}$ & $\begin{array}{l}\text { DIV change (IDR) } \\
=\text { LED long term demand*nic } \\
\text { Description: desired inventory change } \\
\text { Present in } 1 \text { view: } \\
\text { - View } 1 \\
\text { Used by: } \\
\text { - DII - desired inventory investment }\end{array}$ \\
\hline Default & $\begin{array}{c}\text { macroeconomic } \\
\text { models covid-19 } \\
2020 \\
\text { (Default) }\end{array}$ & $\begin{array}{c}\# 21 \\
\mathrm{~A} \\
\mathrm{VAB}\end{array}$ & $\begin{array}{l}\text { expected labour supply (people) } \\
\text { = labour supply*(1-Nru) } \\
\text { Description: available labour supply after NRU (natural unemployment) } \\
\text { Present in 1 view: } \\
\text { - View } 1 \\
\text { Used by: }\end{array}$ \\
\hline
\end{tabular}




\begin{tabular}{|c|c|c|c|}
\hline & & & $\begin{array}{ll}\text { - } & \text { DE desired emplyment - desired employment } \\
\text { - } & \text { Lw change - changes in employment }\end{array}$ \\
\hline Default & $\begin{array}{l}\text { macroeconomic } \\
\text { models covid-19 } \\
2020 \\
\text { (Default) }\end{array}$ & $\begin{array}{c}\# 25 \\
\text { A } \\
\text { Wha }\end{array}$ & $\begin{array}{l}\text { fraction investment }(\mathrm{dmnl}) \\
=\text { IF THEN ELSE( Time }<10,0.07,0.09) \\
\text { Description: } \text { fraction of investment growth } \\
\text { Present in } 1 \text { view: } \\
\text { - View } 1 \\
\text { Used by: } \\
\text { - available investment - available investment }\end{array}$ \\
\hline Default & $\begin{array}{l}\text { macroeconomic } \\
\text { models covid-19 } \\
2020 \\
\text { (Default) }\end{array}$ & $\begin{array}{l}\# 26 \\
\mathrm{C} \\
\mathrm{VAB}\end{array}$ & $\begin{array}{l}\text { fraction labor supply }(\mathrm{dmnl}) \\
=0.485 \\
\text { Description: } \text { fraction of labour supply - share of labour and population } \\
\text { Present in } 1 \text { view: } \\
\text { - View } 1 \\
\text { Used by: } \\
\text { - labour supply }\end{array}$ \\
\hline Default & $\begin{array}{l}\text { macroeconomic } \\
\text { models covid-19 } \\
2020 \\
\text { (Default) }\end{array}$ & $\begin{array}{l}\# 27 \\
\mathrm{C} \\
\mathrm{WAB}\end{array}$ & $\begin{array}{l}\text { fraction of GT government transfer }(\mathrm{dmnl}) \\
=0.03 \\
\text { Description: a fraction of the government transfer } \\
\text { Present in } 1 \text { view: } \\
\text { - } \quad \text { View } 1\end{array}$ \\
\hline
\end{tabular}




\begin{tabular}{|c|c|c|c|}
\hline & & & $\begin{array}{l}\text { Used by: } \\
\text { - } \quad \text { GT Government Transfer - the government transfer }\end{array}$ \\
\hline Default & $\begin{array}{l}\text { macroeconomic } \\
\text { models covid-19 } \\
2020 \\
\text { (Default) }\end{array}$ & $\begin{array}{l}\# 30 \\
\text { F,A } \\
\text { WAb } \\
\text { 虑 }\end{array}$ & $\begin{array}{l}\text { FS final sales (IDR/Year) } \\
=\text { actual investment }+\mathrm{C} \text { consumption }+\mathrm{GS} \text { government spending } \\
\text { Description: the final sales } \\
\text { Present in } 1 \text { view: } \\
\text { Used by: } \\
\text { View } 1 \\
\quad \text { AG Aggregate demand - the aggregate demand } \\
\text { IV inventory }\end{array}$ \\
\hline Default & $\begin{array}{l}\text { macroeconomic } \\
\text { models covid-19 } \\
2020 \\
\text { (Default) }\end{array}$ & $\begin{array}{c}\# 31 \\
\mathrm{C} \\
\mathrm{WAB}\end{array}$ & $\begin{array}{l}\text { growth fraction }(\mathrm{dmnl}) \\
=0.04 \\
\text { Present in } 1 \text { view: } \\
\quad \text { View } 1\end{array}$ \\
\hline Default & $\begin{array}{l}\text { macroeconomic } \\
\text { models covid-19 } \\
2020 \\
\text { (Default) }\end{array}$ & $\begin{array}{l}\# 32 \\
\text { A } \\
\text { VAB }\end{array}$ & $\begin{array}{l}\text { GS government spending }(\mathrm{IDR} / \mathrm{Year}) \\
=\text { GS government spending initial* }{ }^{*}\left((1+\text { fraction Government spending })^{\wedge}(\text { Time/time unit-INITIAL TIME/time unit })\right) \\
\text { Description: government spending } \\
\text { Present in } 1 \text { view: } \\
\text { • } \quad \text { View } 1 \\
\text { Used by: } \\
-\quad \text { FS final sales }- \text { the final sales }\end{array}$ \\
\hline
\end{tabular}




\begin{tabular}{|c|c|c|c|}
\hline Default & $\begin{array}{c}\text { macroeconomic } \\
\text { models covid-19 } \\
2020 \\
\text { (Default) }\end{array}$ & $\begin{array}{c}\# 33 \\
\text { C } \\
\text { VABb }\end{array}$ & $\begin{array}{l}\text { GS government spending initial (IDR/Year) } \\
=9.08 \mathrm{e}+13 \\
\text { Description: initial government spending } \\
\text { Present in } 1 \text { view: } \\
\text { Used by: } \\
\text { View } 1 \\
\quad \text { GS government spending - government spending }\end{array}$ \\
\hline Default & $\begin{array}{c}\text { macroeconomic } \\
\text { models covid-19 } \\
2020 \\
\text { (Default) }\end{array}$ & $\begin{array}{l}\# 34 \\
\text { LI,A } \\
\text { VAt }\end{array}$ & $\begin{array}{l}\text { GT Government Transfer }(\text { IDR/Year }) \\
=\text { IF THEN ELSE }(\text { Time }>=20,0,((\text { Yo output initial } * \text { fraction of GT government transfer }) *((1+\text { percentage growth } \\
\left.\left.\left.\text { GT })^{\wedge}(\text { Time/time unit-INITIAL TIME/time unit })\right)\right)\right) \\
\text { Description: the government transfer } \\
\text { Present in } 1 \text { view: } \\
\text { • View } 1 \\
\text { Used by: } \\
\quad \quad \quad \text { CDY - Current Disposible Income } \\
\text { PY permanent income - the permanent income }\end{array}$ \\
\hline Default & $\begin{array}{c}\text { macroeconomic } \\
\text { models covid-19 } \\
2020 \\
\text { (Default) }\end{array}$ & $\begin{array}{c}\# 35 \\
\mathrm{C} \\
\mathrm{VA} \\
\mathrm{VAB}\end{array}$ & $\begin{array}{l}\text { household financial assets (IDR) } \\
=6.99 \mathrm{e}+14 \\
\text { Present in } \mathbf{1} \text { view: } \\
\text { Used by: } \\
\text { View } 1 \\
\quad \text { permanent income from financial assets }\end{array}$ \\
\hline Default & $\begin{array}{c}\text { macroeconomic } \\
\text { models covid-19 } \\
2020 \\
\text { (Default) }\end{array}$ & $\begin{array}{l}\# 36 \\
\text { C } \\
\text { VAt }\end{array}$ & $\begin{array}{l}\text { initial investment (IDR/Year) } \\
=2.759 \mathrm{e}+14 \\
\text { Description: } \text { initial investment }(2000) \\
\text { Present in } \mathbf{1} \text { view: } \\
\text { Used by: } \\
\text { View } 1 \\
\quad \text { available investment - available investment }\end{array}$ \\
\hline Default & $\begin{array}{c}\text { macroeconomic } \\
\text { models covid-19 } \\
2020 \\
\text { (Default) }\end{array}$ & $\begin{array}{c}\# 38 \\
\mathrm{~L} \\
\text { 幽 }\end{array}$ & $\begin{array}{l}\text { IV inventory (IDR) } \\
=\int \text { Y output-FS final sales } d t+[\text { nic* } * \text { Yo output initial }] \\
\text { Present in } 1 \text { view: } \\
\text { Used by: } \\
\text { View } 1 \\
\quad \text { DII - desired inventory investment }\end{array}$ \\
\hline
\end{tabular}




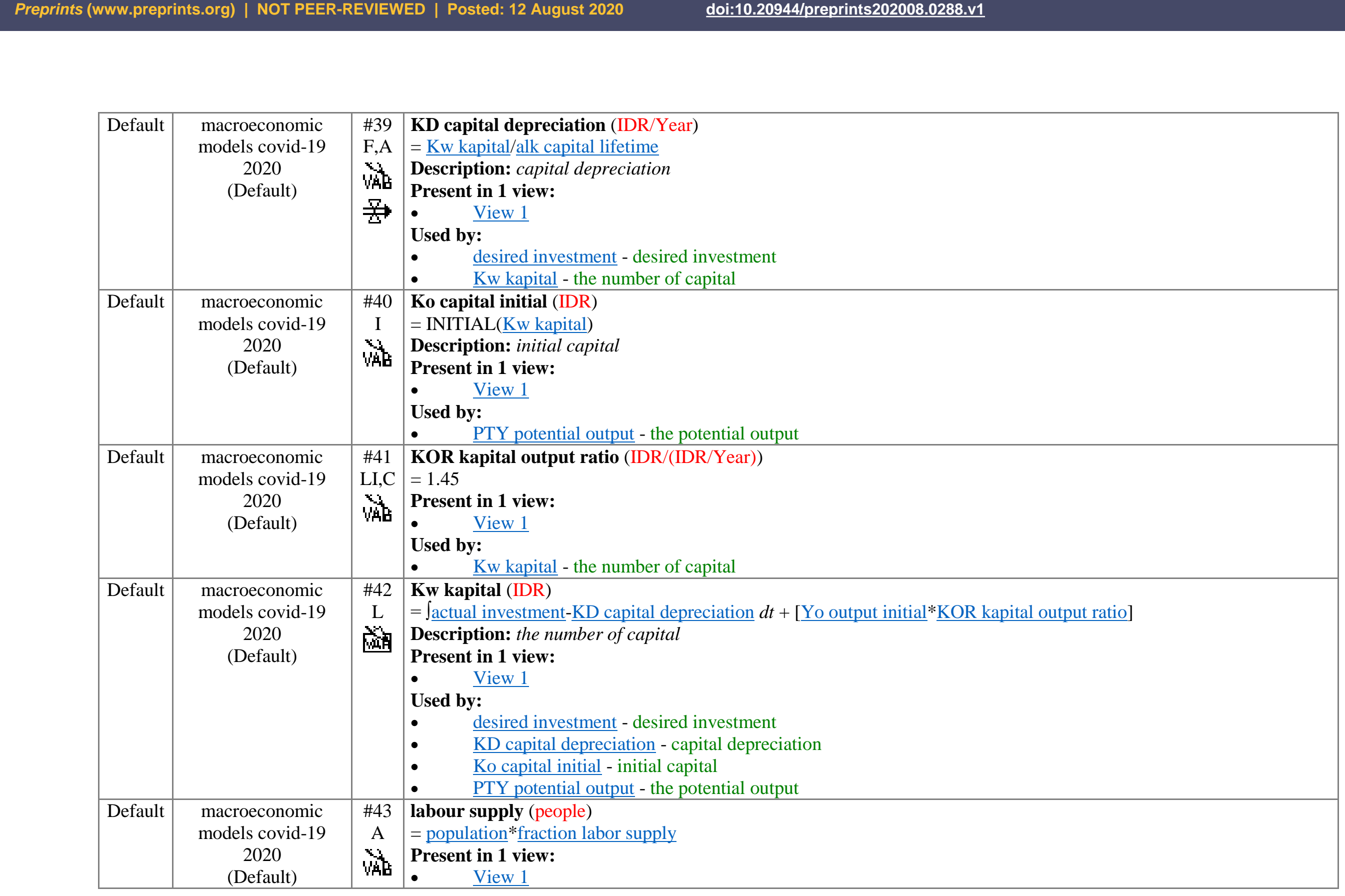




\begin{tabular}{|c|c|c|c|}
\hline & & & $\begin{array}{l}\text { Used by: } \\
\text { - } \quad \text { actual unemployment - actual unemployment } \\
\text { - } \quad \text { expected labour supply - available labour supply after NRU (natural unemployment) } \\
\text { Lw change - changes in employment } \\
\text { umployed people - unemployed people }\end{array}$ \\
\hline Default & $\begin{array}{l}\text { macroeconomic } \\
\text { models covid-19 } \\
2020 \\
\text { (Default) }\end{array}$ & $\begin{array}{l}\# 44 \\
\mathrm{~F}, \mathrm{~A} \\
\mathrm{VAB} \\
\mathrm{F}\end{array}$ & $\begin{array}{l}\text { LED growth }((\mathrm{IDR} / \mathrm{Year}) / \mathrm{Year}) \\
=(\text { AG Aggregate demand-LED long term demand }) / \text { tsld } \\
\text { Description: changes in long expected demand } \\
\text { Present in } 1 \text { view: } \\
\text { - View } 1 \\
\text { Used by: } \\
\quad \quad \text { LED long term demand - long expected demand }\end{array}$ \\
\hline Default & $\begin{array}{l}\text { macroeconomic } \\
\text { models covid-19 } \\
2020 \\
\text { (Default) }\end{array}$ & $\begin{array}{l}\# 45 \\
\mathrm{~L} \\
\mathrm{M} \\
\mathrm{M}\end{array}$ & $\begin{array}{l}\text { LED long term demand (IDR/Year) } \\
=\int \text { LED growth } d t+[\text { Yo output initial] } \\
\text { Description: long expected demand } \\
\text { Present in } 1 \text { view: } \\
\text { - } \quad \text { View } 1 \\
\text { Used by: } \\
\text { - } \quad \text { Desired capital - desired capital } \\
\text { - } \quad \text { DIV change - desired inventory change } \\
\text { LED growth - changes in long expected demand }\end{array}$ \\
\hline Default & $\begin{array}{l}\text { macroeconomic } \\
\text { models covid-19 } \\
2020 \\
\text { (Default) }\end{array}$ & $\begin{array}{l}\# 46 \\
\text { LI,C } \\
\text { VAB }\end{array}$ & $\begin{array}{l}\text { Lo labour initial (people) } \\
=9.323 \mathrm{e}+07 \\
\text { Description: initial labour } \\
\text { Present in } 1 \text { view: } \\
\text { Used by: } \\
\text { View } 1 \\
\quad \text { LW labour - the number of labour } \\
\quad \text { PTY potential output - the potential output }\end{array}$ \\
\hline Default & $\begin{array}{l}\text { macroeconomic } \\
\text { models covid-19 } \\
2020 \\
\text { (Default) }\end{array}$ & $\begin{array}{l}\# 47 \\
\mathrm{~F}, \mathrm{~A} \\
\text { VAB } \\
\text { 居 }\end{array}$ & $\begin{array}{l}\text { Lw change (people/Year) } \\
=(\text { IF THEN ELSE(Lw labour<expected labour supply :AND: Time >8, max }(\mathrm{DE} \text { desired emplyment/tae*adjustment } \\
\text { factor2,(labour supply/expected labour supply } \\
\text { *((delayed unemployment-relationships between Y output and employment)*labour supply/tae) } \\
)), \text { MIN(DE desired emplyment/tae*adjustment factorl,(labour supply/expected labour supply*adjustment } \\
\text { factor } 1 *((\text { delayed unemployment-relationships between Y output and employment }\end{array}$ \\
\hline
\end{tabular}




\begin{tabular}{|c|c|c|c|}
\hline & & & $\begin{array}{l}\text { *adjustment factor1)*labour supply/tae))) ))Description: changes in employment } \\
\text { Present in } 1 \text { view: } \\
\text { - View } 1 \\
\text { Used by: } \\
\text { - } \quad \text { Lw labour - the number of labour }\end{array}$ \\
\hline Default & $\begin{array}{l}\text { macroeconomic } \\
\text { models covid-19 } \\
2020 \\
\text { (Default) }\end{array}$ & $\begin{array}{l}\# 49 \\
\mathrm{~L} \\
\mathrm{~m}\end{array}$ & $\begin{array}{l}\text { NE Net export (IDR/Year) } \\
=\int \text { NE net export change } d t+[1.462 \mathrm{e}+14] \\
\text { Description: } \text { net export import } \\
\text { Present in } 1 \text { view: } \\
\text { - View } 1 \\
\text { Used by: } \\
\text { - } \quad \text { AG Aggregate demand }- \text { the aggregate demand } \\
\text { NE net export change - net export-import change }\end{array}$ \\
\hline Default & $\begin{array}{l}\text { macroeconomic } \\
\text { models covid-19 } \\
2020 \\
\text { (Default) }\end{array}$ & $\begin{array}{l}\# 50 \\
F, A \\
\text { VAt } \\
\text { 居 }\end{array}$ & $\begin{array}{l}\text { NE net export change (IDR/(Year* Year)) } \\
\text { = fraction of net export*NE Net export } \\
\text { Description: } \text { net export-import change } \\
\text { Present in } 1 \text { view: } \\
\text { - View } 1 \\
\text { Used by: } \\
\text { - NE Net export - net export import }\end{array}$ \\
\hline Default & $\begin{array}{l}\text { macroeconomic } \\
\text { models covid-19 } \\
2020 \\
\text { (Default) }\end{array}$ & $\begin{array}{l}\# 51 \\
\text { LI,C } \\
\text { VAB }\end{array}$ & $\begin{array}{l}\text { nic }(\text { Year }) \\
=0.3 \\
\text { Description: Normal Inventory Coverage } \\
\text { Present in } 1 \text { view: } \\
\text { - View } 1\end{array}$ \\
\hline
\end{tabular}




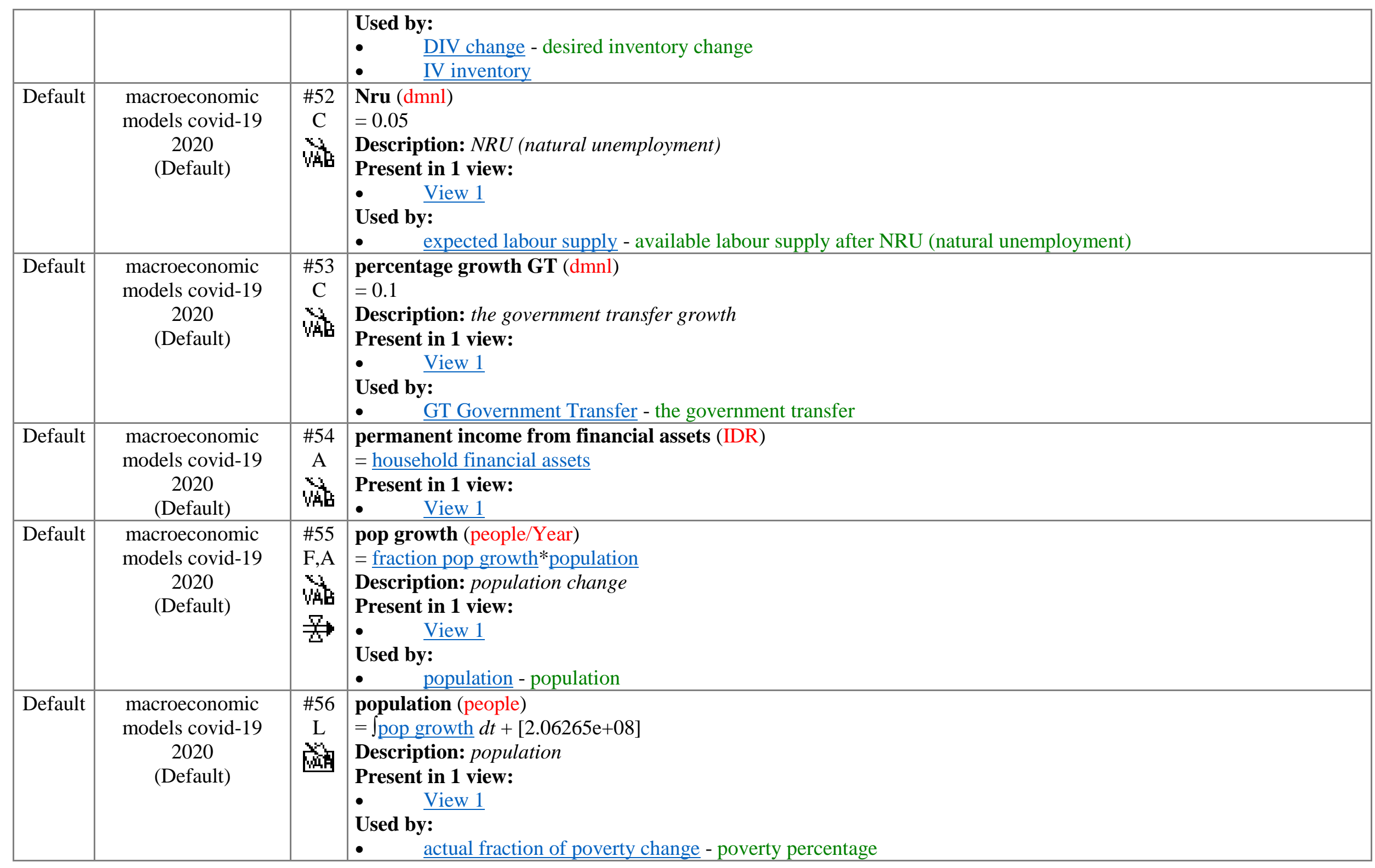




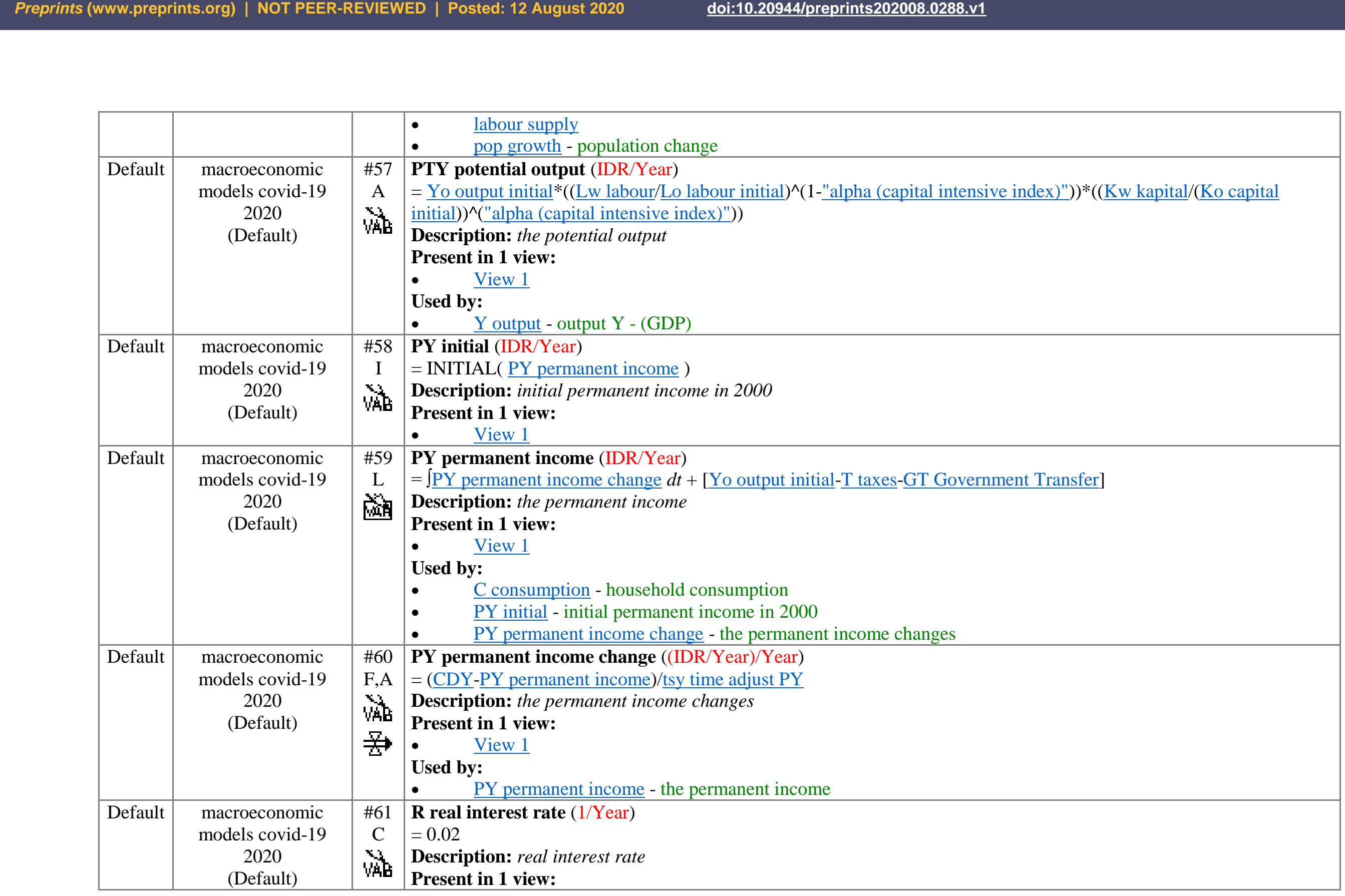




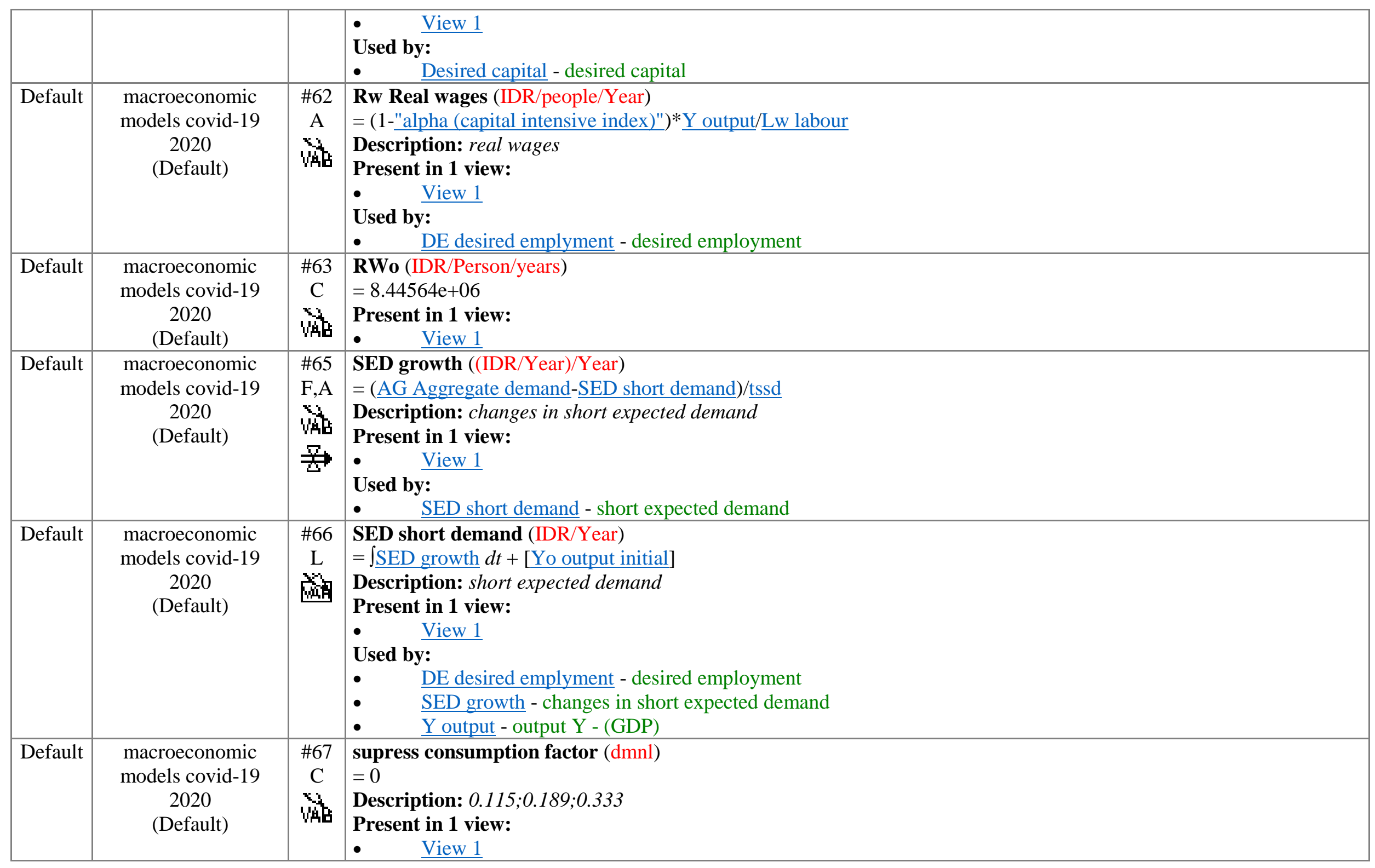




\begin{tabular}{|c|c|c|c|}
\hline & & & $\begin{array}{l}\text { Used by: } \\
\text { - } \quad \text { C consumption - household consumption }\end{array}$ \\
\hline Default & $\begin{array}{l}\text { macroeconomic } \\
\text { models covid-19 } \\
2020 \\
\text { (Default) }\end{array}$ & $\begin{array}{l}\# 70 \\
\mathrm{C} \\
\mathrm{VA}\end{array}$ & $\begin{array}{l}\text { tai }(\text { Year) } \\
=0.4 \\
\text { Description: delay time of desired inventory } \\
\text { Present in } \mathbf{1} \text { view: } \\
\bullet \quad \text { View } 1 \\
\text { Used by: } \\
-\quad \text { DII - desired inventory investment }\end{array}$ \\
\hline Default & $\begin{array}{c}\text { macroeconomic } \\
\text { models covid-19 } \\
2020 \\
\text { (Default) }\end{array}$ & $\begin{array}{c}\# 71 \\
\mathrm{C} \\
\mathrm{V} \\
\mathrm{VAB}\end{array}$ & $\begin{array}{l}\text { tak delaytime investment (Year) } \\
=3 \\
\text { Description: delay time of investment } \\
\text { Present in } \mathbf{1} \text { view: } \\
\text { - View } 1 \\
\text { Used by: } \\
\quad \quad \text { desired investment - desired investment }\end{array}$ \\
\hline Default & $\begin{array}{l}\text { macroeconomic } \\
\text { models covid-19 } \\
2020 \\
\text { (Default) }\end{array}$ & $\begin{array}{c}\# 72 \\
\mathrm{C} \\
\mathrm{VAB}\end{array}$ & $\begin{array}{l}\operatorname{tap}(\text { Year }) \\
=0.5 \\
\text { Description: delay time of poverty change } \\
\text { Present in } 1 \text { view: } \\
\text { - } \quad \text { View } 1\end{array}$ \\
\hline
\end{tabular}




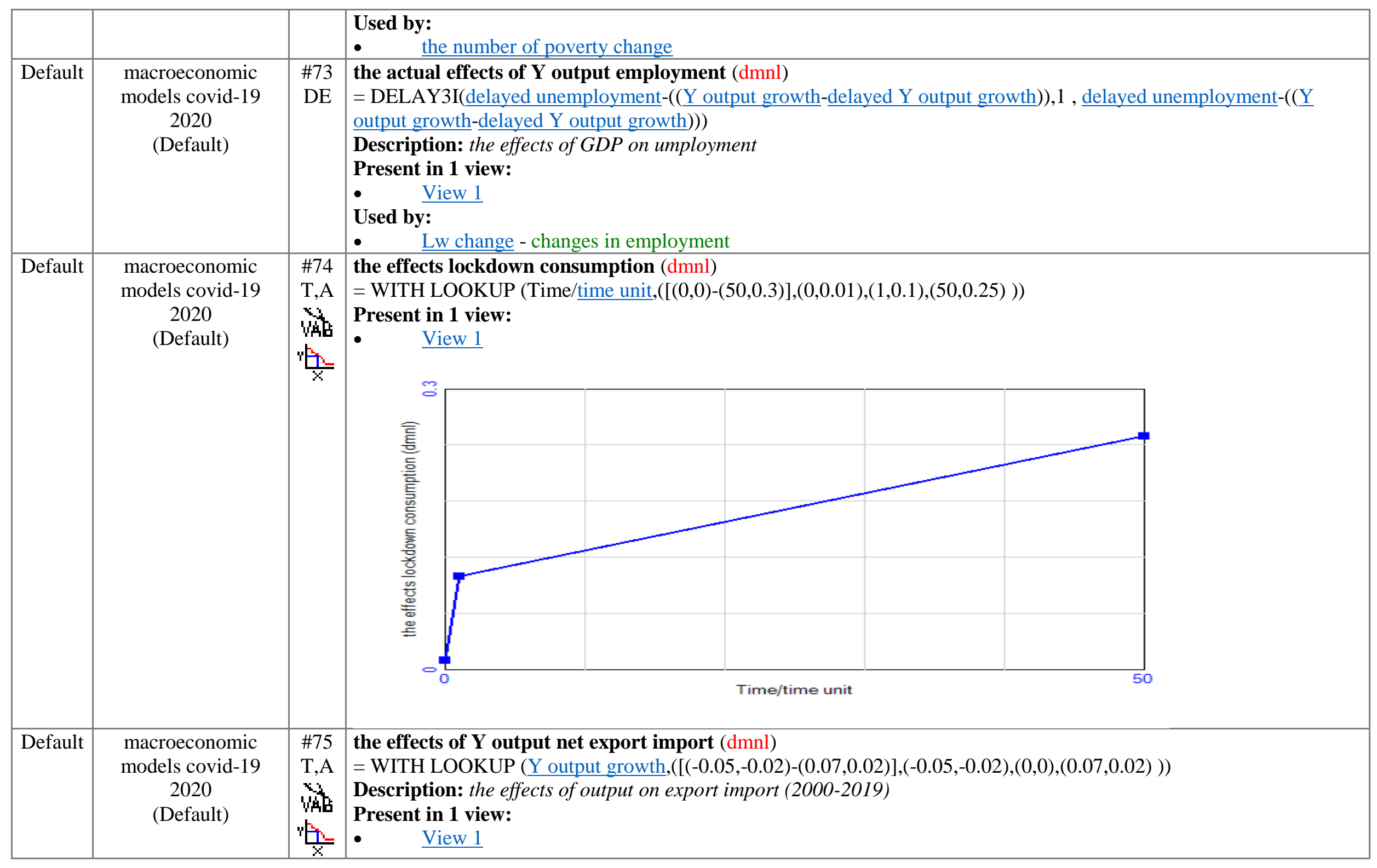

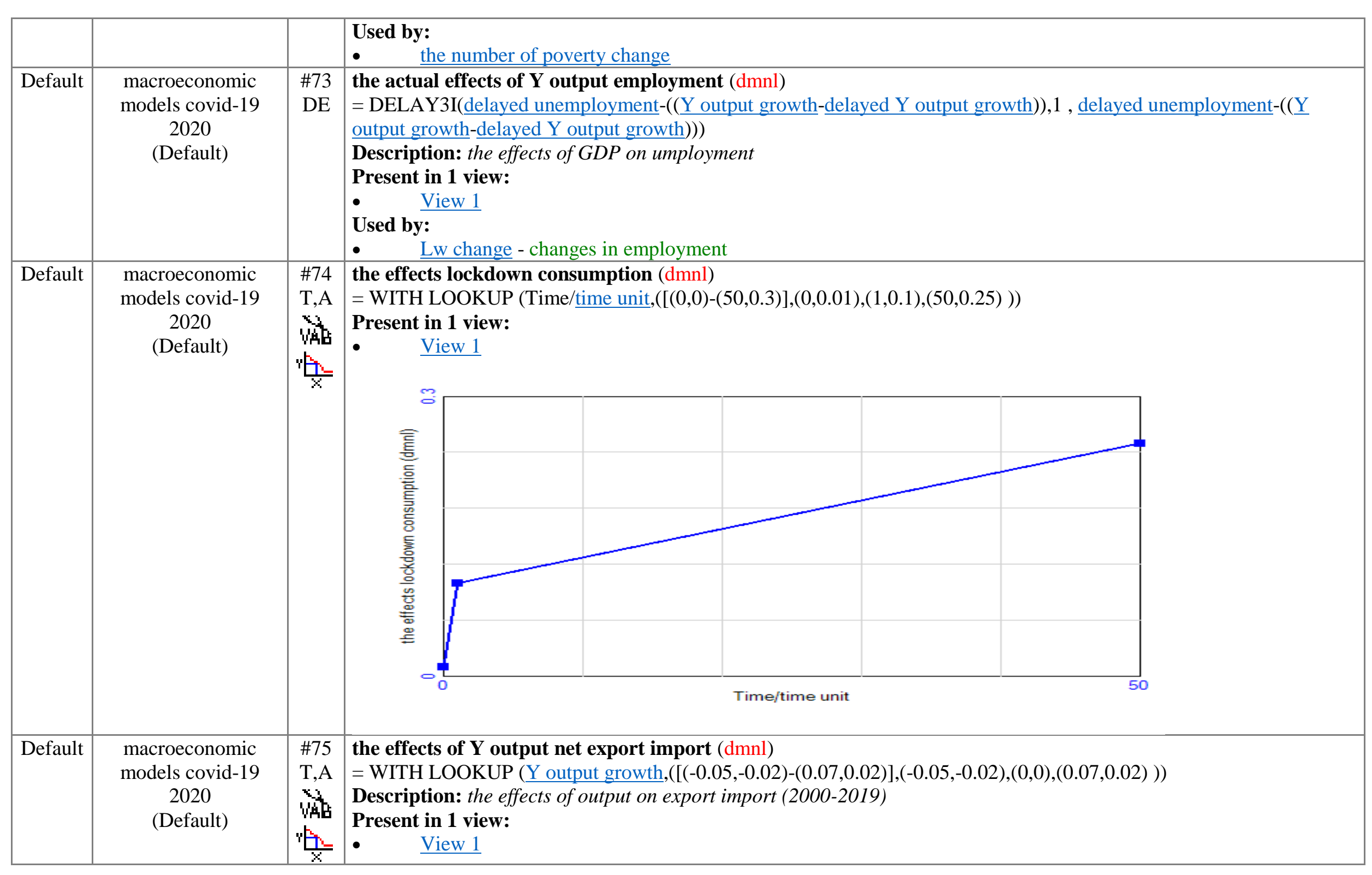




\begin{tabular}{|l|l|l|l|l|}
\hline & Used by: \\
\hline & & \\
fraction of net export - fraction of export-import
\end{tabular}

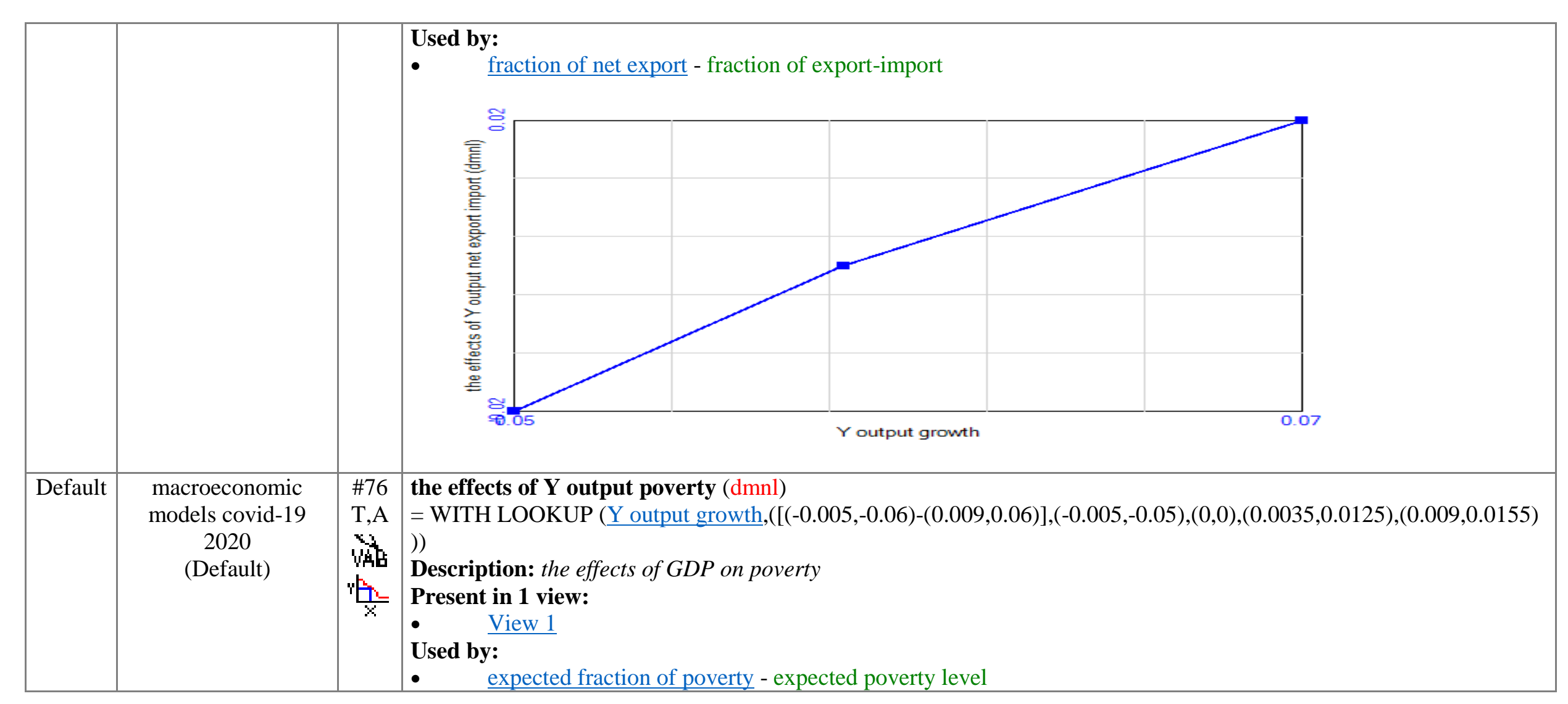




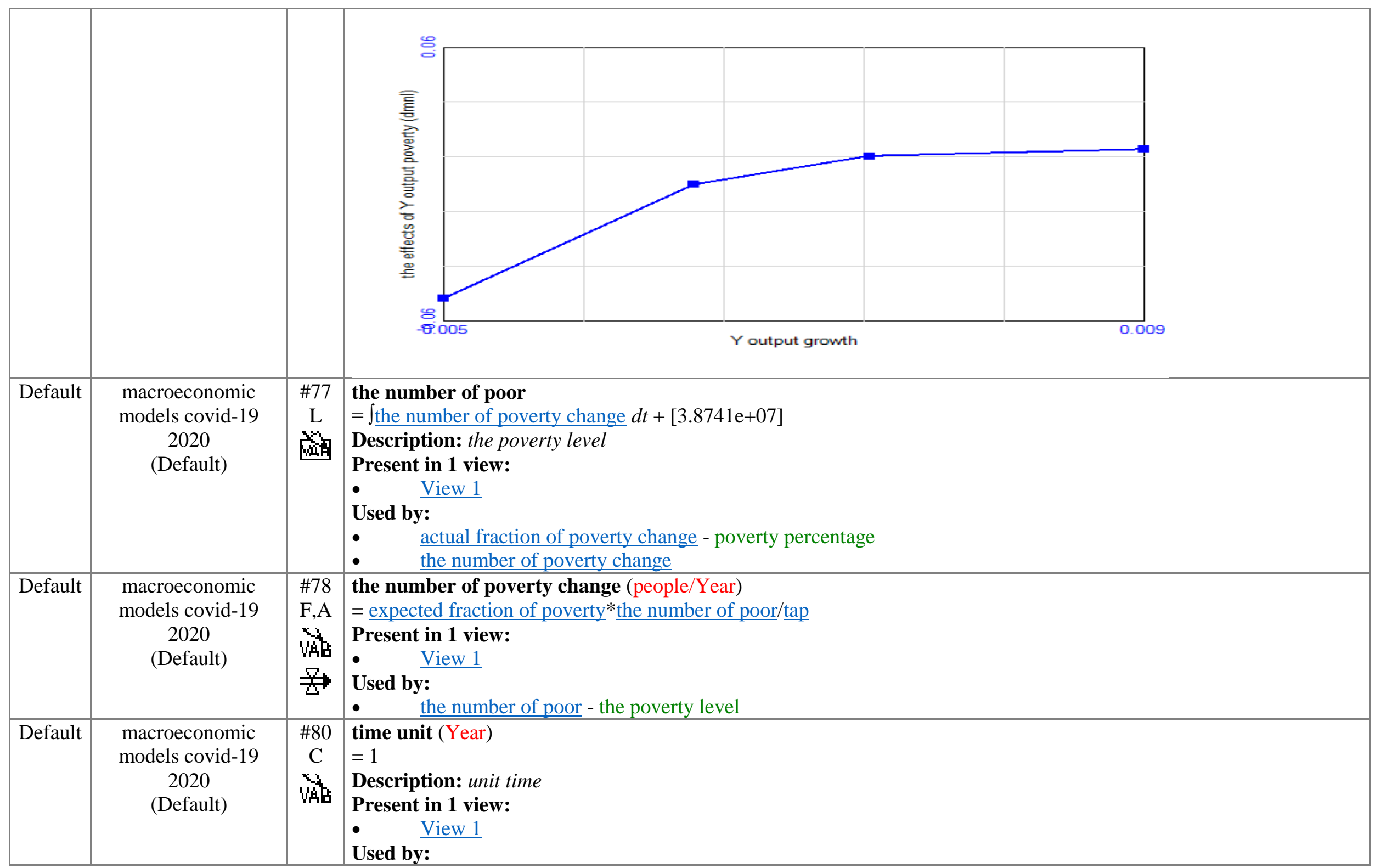




\begin{tabular}{|c|c|c|c|}
\hline & & & $\begin{array}{ll}\text { - } & \text { available investment - available investment } \\
\text { - } & \text { GS government spending - government spending } \\
\text { - } & \text { GT Government Transfer - the government transfer } \\
\end{array}$ \\
\hline Default & $\begin{array}{l}\text { macroeconomic } \\
\text { models covid-19 } \\
2020 \\
\text { (Default) }\end{array}$ & $\begin{array}{c}\# 81 \\
\mathrm{C} \\
\mathrm{VAB}\end{array}$ & $\begin{array}{l}\text { tr tax rate }(\mathrm{dmnl}) \\
=0.11 \\
\text { Description: a fraction of the government tax } \\
\text { Present in } 1 \text { view: } \\
\text { - } \quad \text { View } 1 \\
\text { Used by: } \\
-\quad \underline{T \text { taxes }}\end{array}$ \\
\hline Default & $\begin{array}{l}\text { macroeconomic } \\
\text { models covid-19 } \\
2020 \\
\text { (Default) }\end{array}$ & $\begin{array}{c}\# 82 \\
\mathrm{C} \\
\mathrm{VAB}\end{array}$ & $\begin{array}{l}\text { TSAY Time to Smooth Average Output (Year) } \\
=3 \\
\text { Present in } 1 \text { view: } \\
\text { - } \quad \text { View } 1\end{array}$ \\
\hline Default & $\begin{array}{l}\text { macroeconomic } \\
\text { models covid-19 } \\
2020 \\
\text { (Default) }\end{array}$ & $\begin{array}{c}\# 83 \\
\mathrm{C} \\
\mathrm{VAB}\end{array}$ & $\begin{array}{l}\text { tsld (Year) } \\
=4 \\
\text { Description: delay time of long expected demand } \\
\text { Present in } 1 \text { view: } \\
\text { - } \quad \text { View } 1 \\
\text { Used by: } \\
\text { - LED growth - changes in long expected demand }\end{array}$ \\
\hline Default & $\begin{array}{l}\text { macroeconomic } \\
\text { models covid-19 } \\
2020 \\
\text { (Default) }\end{array}$ & $\begin{array}{c}\# 84 \\
\mathrm{C} \\
\mathrm{WA}\end{array}$ & $\begin{array}{l}\text { tssd (Year) } \\
=0.5 \\
\text { Description: delay time of short expected demand } \\
\text { Present in } 1 \text { view: } \\
\bullet \quad \text { View } 1 \\
\text { Used by: } \\
-\quad \text { SED growth - changes in short expected demand }\end{array}$ \\
\hline Default & $\begin{array}{l}\text { macroeconomic } \\
\text { models covid-19 } \\
2020 \\
\text { (Default) }\end{array}$ & $\begin{array}{l}\# 85 \\
\mathrm{C} \\
\mathrm{VAB}\end{array}$ & $\begin{array}{l}\text { tsy time adjust PY (Year) } \\
=1 \\
\text { Present in } \mathbf{1} \text { view: } \\
\text { : } \quad \text { View } 1 \\
\text { Used by: } \\
-\quad \text { PY permanent income change - the permanent income changes }\end{array}$ \\
\hline
\end{tabular}




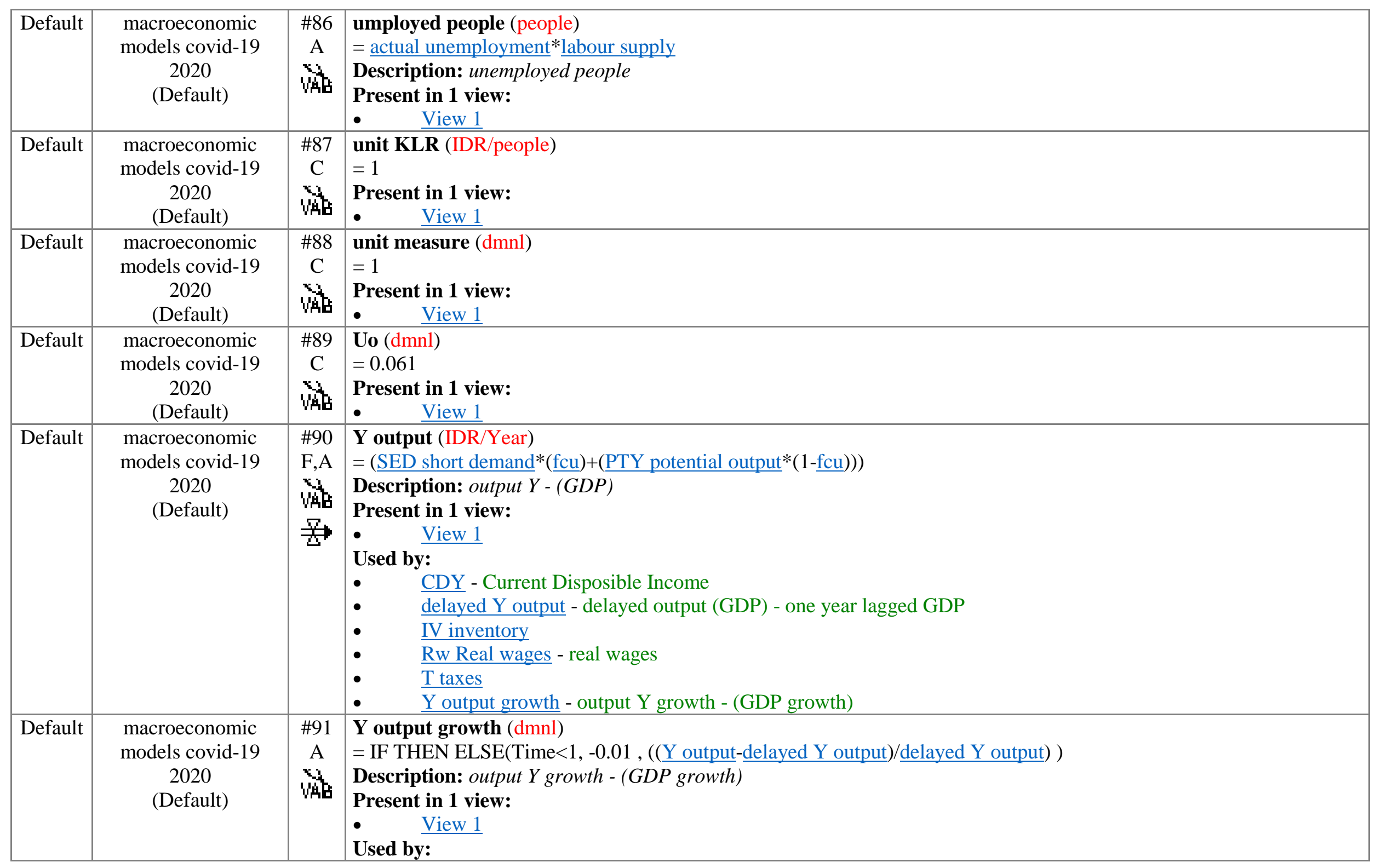




(1)

.

(

(1)

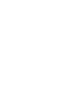

Cons

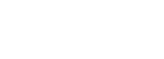

